\title{
Sustainable Management of Soil Potassium - A Crop Rotation Oriented Concept
}

\author{
Witold Grzebisz, Witold Szczepaniak, \\ Jarosław Potarzycki and Remigiusz Łukowiak \\ Additional information is available at the end of the chapter \\ http://dx.doi.org/10.5772/53185
}

\section{Introduction}

Modern agriculture is under pressure of two contradictory challenges reflected by the increasing world's population on one hand, and the magnitude of food production, on the other hand. In the period ranging from 1960 to 2010, the population doubled from 3 to more than 6 billions, while the production of cereals tripled, a success which expressed by a significant yield increase per ha (from $1.09 \mathrm{t} \mathrm{ha}^{-1}$ in 1960 to $3.0 \mathrm{t} \mathrm{ha}^{-1}$ in 2010) [1]. The major reason of such yield increase was a marked progress in plant breeding, resulting in generations of new, high-yielding varieties [2]. This process run in parallel with the increase in fertilizers, pesticides production and consumption, hence enabling to cover nutritional needs and supporting the health of highyielding crops. The intensive production gain, based on enormous consumption of non-renewable resources, especially fuel and simultaneously nutrients such as nitrogen and phosphorus was, however, concomitant with their low use efficiency. This type of agriculture intensification created, in many regions of the world a threat to environment, at both local and globalscale. There are numerous examples stressing the negative impact of intensive agriculture on environment. Agricultural practices are responsible for the majority of ammonia and to a great part for nitrogen oxide's emission to the atmosphere. Pollution of ground-water by nitrates and phosphates originating from both arable soils and surface waters was recognized the earliest. All these negative effects were the reason for the increased activity of local societies in the 70 and 80 -ies of the $\mathrm{XX}$ century, resulting in the development of legal instruments protecting the environment, for instance the Nitrate Directive $[3,4,5]$.

The complexity of agricultural impact on human life and the increasing awareness of environmental threats was the boosting argument for elaborating a concept of sustainable agriculture growth [6]. The core of this concept relies on an assuming that agricultural systems 
should be managed in a way covering current needs of present human being's population without negative impact on its performance in the future. The change of classical technologies to fulfill both goals cannot be, however, achieved discrediting existing production methods. The analysis of two food supply scenarios, developed in the 90-ies, i.e., Yield Oriented Agriculture (YOA) and Environment Oriented Agriculture (EOA), implicitly shows that the second scenario guaranties the only moderate diet in 2040. By following this food production strategy, food shortage is expected in some regions of the world [7]. Therefore, the main challenges of modern agriculture are related to the improvement of classical production technologies. The future development scenarios cannot follow the concept of "sustainable intensification." This strategy, developed for low-input agriculture, assumes the substitution of external inputs by naturally available resources, both physical and human [8]. Therefore, the key challenge of agriculture is to increase resources use efficiency in all systems, independently on their current intensity. The general strategies of technological changes should include: i) improvement of water unit productivity, ii) increasing size of soil natural pools, i.e., resources affecting its fertility (organic carbon, macro- and micro-nutrients), iii) reorientation of plant crop management of a single crop to the crop rotation iv) adopting no-till farming and conservation agriculture $[2,5,9,10,11]$.

The efficient allocation of production means for improving yields and securing the environment, requires a deep insight into processes responsible for crop's productivity. It is well recognized, that crop plant development during the growth season is controlled by numerous factors, both depended and independent on farmer's activity. All these factors have been arranged in a manner taking into account the degree of their impact on plant growth and productivity [12]. Four hierarchical levels of production factors and respective yield levels may be distinguished: i) potential, ii) water limited, iii) nutrient limited, iv) actual [13]. The first level of crop plant productivity is defined by climatic factors such as solar radiation, fixed by geographical location of the field. The potential productivity of the presently cultivated variety is defined by the capacity of its canopy to intercept solar radiation. This yield category is achievable, provided ample supply of water and nutrients during all stages of yield development [14]. For example, in Europe, the average yield potential of wheat was evaluated for the period 1996-2005 at the level of $10.4 \mathrm{t} \mathrm{ha}^{-1}$, however, ranged from $6.9 \mathrm{in}$ Bulgaria to $12.7 \mathrm{tha}^{-1}$ in Ireland [15], depending on climatic factors.

Lal [10] has made an important remark concerning the exploitation of the yield potential of modern species. He pointed out that ..."improved germplasm cannot extract water/ nutrients from degraded/depleted soils".... Water supply to plants during the vegetative season is considered as the key limiting factor, defining the maximum achievable yield under physical conditions of the currently cropped field. In other words, this factor determines the site-specific, i.e., locally realizable yield. Any shortage of water supply throughout the growth season, especially during critical stages of yield formation is the primary reason of yield losses. In Europe, the water limited yield (WLY) is fixed at levels, showing declining trends in the directions extending from the West to the East and the South of the continent. For Ireland, it has been calculated at the level of 8.5, Germany and Poland - 6.5, Bulgaria, Romania $-4.5 \mathrm{t} \mathrm{ha}^{-1}[16]$. However, WLYs show significant differences in comparison to the 
respective yield potential, which is as follows: 4.2, 3.4, 3.6, 4.6, $2.4 \mathrm{t} \mathrm{ha}^{-1}$, respectively. This virtually un-harvested portion of the potential yield has been termed as the yield gap.

The third level of crop productivity depends on the supply of nutrients. However, production effects of applied nutrients are different, depending on a particular yield forming characteristic. Therefore, they can be classified to one of two main groups. The first one comprises only one nutrient, i.e., nitrogen. Its superiority over others is due to the decisive impact on primary plant physiological processes. The most important are those responsive for dry matter production, and its subsequent partitioning among organs during the whole life cycle of a plant [17]. Therefore, water and nitrogen are considered as the key limiting factors in the realization of the crop yield potential.. The effect of both factors on in-season crop performance depends on the supply of other nutrients. All of them are essential for the adequate plant growth, but are considered only as "secondary" in terms of their impact on yield performance and yielding potential exploration. Therefore, the Nutrient Limited Yield Gap (NLYG) can be related to the degree of both water- and nitrogen-use efficiency, i.e, WUE and NUE, respectively. The first one creates a milieu for nitrogen uptake and its further internal utilization. Thereby, the yield gap, due to inadequate uptake of nitrogen can be overcome provided the balanced supply of other nutrients. The question, remains how to match a crop demand for nitrogen and other nutrients in time and space?

The main assumption of efficient nitrogen use is to apply nitrogen fertilizer in accordance to crop plant demands, which are variable during consecutive stages of growth. Farmers are aware of nitrogen and other nutrient's importance for increasing yield of growing crops as a prerequisite of high yield. However, they frequently make savings of their use, in turn decreasing nitrogen production efficiency. The key attribute of nitrogen-oriented crop production is its relatively low recovery from applied fertilizers, in turn negatively impacting the environment $[4,9]$. In addition, the unbalanced nitrogen use leads to the depletion of natural resources of other nutrients required by crop plants. This situation, as shown in Fig. 1, is typical for countries of the second and third group. In many Central-East European countries, yields of wheat decreased significantly in the 90-ies. The declining soil fertility is the main cause of the considerable year-to-year variability of harvested yields. The first step in reorientation of current agriculture production into a sustainable way should, therefore, rely on the improvement of phosphorus and potassium management. The best example of this trend is China, which doubled during the last 20 years potassium consumption, resulting in a linear yield increase. The main goals of crop plants fertilization with potassium are to: i) reduce year-to-year variability of harvested yields and ii) increase water- and N-use efficiency.

Potassium is one of the most important nutrients required by crop plants. In plants, its accumulation rate during early stages of growth precedes nitrogen accumulation. Therefore, its supply to plants seems to be decisive for nitrogen utilization, in turn significantly affecting plants growth rate and the degree of yield potential realization. The current status of potassium management in world's agriculture, as presented in Table 1 and Fig. 1, has been evaluated on the basis of potassium fertilizers consumption. Wheat has been considered as an example for assessing, the importance of this nutrient for food production. The consumption of potassium fertilizers in the period from 1986 to 2009 underwent significant changes on the world agricul- 
tural scene. The top wheat producers, mainly European countries and USA, showed a sharp declining trend in potassium usage in 2006-2009 as compared to 1986-1990. In 2005-2009, the group of main potassium consumers, compared to the period 1986-1990 decreased its use to $47 \%$. Unexpectedly, in all these countries, any significant negative effect on wheat yields as induced by the decline in the consumption of potassium was noted. For example, grain yield increase averaged over all studied countries, amounted to $0.9 \mathrm{t} \mathrm{ha}^{-1}$, ranging from -0.3 for Denmark to $+2.17 \mathrm{t}$ ha $^{-1}$ for Belgium (Table 1). Therefore, it can be concluded, that the recommended rates of potassium fertilizer did not fit real wheat requirements, both in time and space.

Potassium consumption pattern for Central and East European countries is much more complicated. It usage showed the same declining trend as in the previous group. However, in the second period, the average K consumption dropped down to $14.3 \%$ of its primary level. The mean change of wheat yield showed increase only for the Russian Federation and stagnation for the Czech Republic. In other countries, a temporary yield gap (TYG), i.e., induced by the decrease in fertilizer's consumption ranged from $-5 \%$ for Serbia to $-23 \%$ for Bulgaria. The relative change $(\Delta \mathrm{Y})$ of wheat yield as presented below, followed the degree of potassium consumption change $(\Delta K)$ :

$$
\Delta \mathrm{Y}=1.47 \Delta \mathrm{K}+114.2 ; \mathrm{R}^{2}=0.66, \mathrm{n}=7 \text { and } \mathrm{P} \leq 0.01
$$

The third group consists of low potassium fertilizer consumers (based on data for the 1986-1990 period). Most of them showed an extremely huge K consumption increase in the period extending from 1990 to 2009. This high progress resulted in the net yield of wheat gain, as presented below:

$$
\Delta \mathrm{Y}=0.13 \Delta \mathrm{K}+4.83 ; \mathrm{R}^{2}=0.61, \mathrm{n}=7 \text { and } \mathrm{P} \leq 0.01
$$

\begin{tabular}{|c|c|c|c|c|c|c|}
\hline \multirow{2}{*}{$\begin{array}{l}\text { Statistical } \\
\text { characteristics }\end{array}$} & \multicolumn{2}{|l|}{$\mathrm{HP}^{2}$} & \multicolumn{2}{|c|}{$\mathbf{1}^{3}$} & \multicolumn{2}{|c|}{$P^{4}$} \\
\hline & $1986-90$ & 2005-2009 & $1986-90$ & 2005-2009 & $1986-90$ & 2005-2009 \\
\hline Average & 51.4 & 23.6 & 53.9 & 7.75 & 4.85 & 14.5 \\
\hline $\begin{array}{l}\text { Standard } \\
\text { deviation }\end{array}$ & 30.2 & 14.7 & 24.7 & 4.46 & 4.46 & 15.4 \\
\hline $\begin{array}{l}\text { Coefficient of } \\
\text { variation, \% }\end{array}$ & 58.8 & 62.3 & 45.8 & 57.5 & 91.9 & 106.1 \\
\hline
\end{tabular}

'source: FAOSTAT, IFADATA, available online 2012-08-07;

${ }^{2}$ group HP (high productive countries): Austria, Belgium, Denmark, France, Germany, Italy, The Netherlands, Spain, United Kingdom, United States of America;

${ }^{3}$ group I (intermediate): Bulgaria, Czech Republic, Hungary, Romania, Russian Federation, Serbia, Slovak Republic, Ukraine; ${ }^{4}$ group P (progressive): Argentina, Australia, China, Egypt, India, Mexico, Turkey.

Table 1. Statistical overview of potassium consumption by wheat producers in two distinct periods ${ }^{1}, \mathrm{~kg} \mathrm{~K}_{2} \mathrm{O} \mathrm{ha}^{-1}$ 
These three examples, presenting potassium management by main wheat producers, implicitly indicate that there is a significant gap between official $\mathrm{K}$ recommend rates and real needs of wheat for fertilizer potassium. It is necessary to agree with opinions expressed frequently by farmers, about the inappropriateness of current nutrient recommendations and especially regarding the transfer of scientific knowledge to agriculture practice. Consequently, each method of $\mathrm{N}$ management requires, firstly, a simple and secondly, a reliable method of other nutrient's recommendations in terms of the amount and of time, as the guarantee of available $\mathrm{N}$ efficient use.

This conceptual review assumes that sustainable potassium management on the field should focus farmer's activity on increasing both: i) the amount of available K pool and ii) access of crops grown in a given cropping sequence to this resources. The primary objective of this paper is to present and explain the scientific background of potassium impact on crop plant's growth and productivity, taking into account their different sensitivity to K supply, both in the required quantity and time. The key objective is to stress the importance of the crop rotation-oriented strategy of potassium management, considered as the low input method. It focusses on covering $\mathrm{K}$ requirements of the most sensitive crop during its critical stages of yield formation. It is also supposed, that K soil sufficiency can be partly achieved by recycling of organic $\mathrm{K}$ sources, taking into account the crop rotation course.

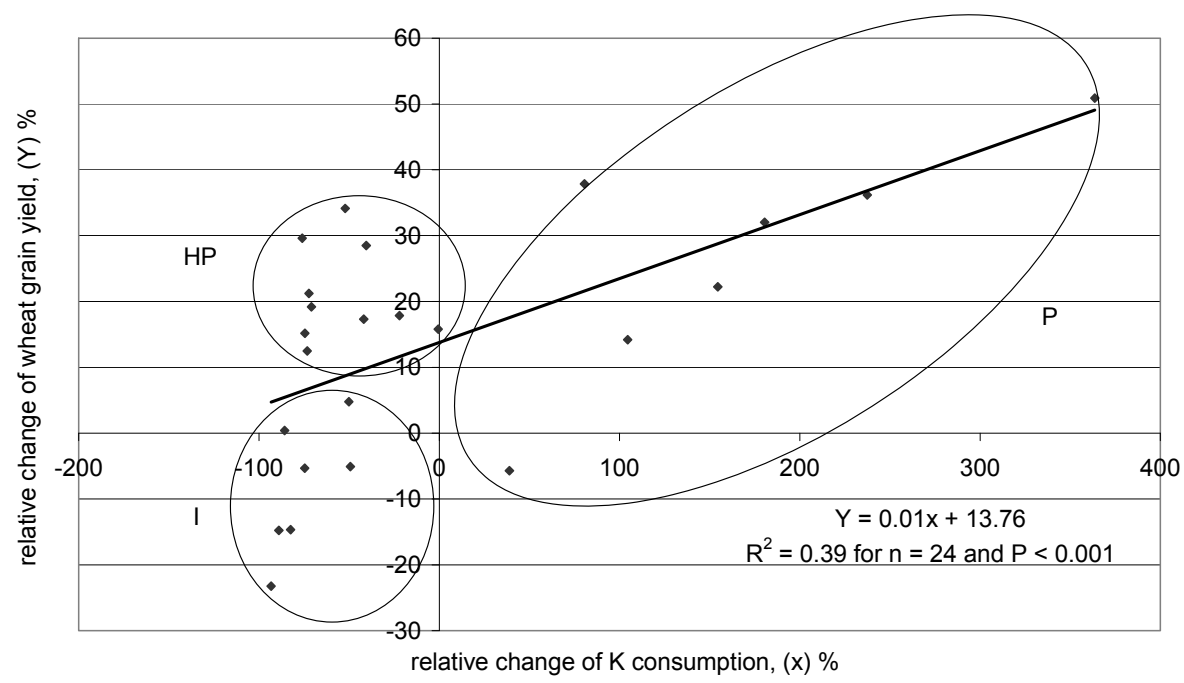

Legend: HP, I, P-groups of countries

Figure 1. Effect of relative change of potassium fertilizer consumption on relative wheat yield change $(1986-1990=$ $100 \%)$. 


\section{Potassium impact on crop plant productivity - Physiological backgrounds}

Potassium (K) is one of the 16 elements needed for plant growth. It is essential in nearly all processes required to sustain the adequate plant growth and its reproduction. Potassium plays a basic role in series of fundamental metabolic and physiological processes in the plant. Plants under potassium deficiency reduce carbon dioxide assimilation and ATP production. Carbon fixation and assimilates transportation to other organs requires potassium. A sufficient supply of potassium is therefore, a background of efficient solar-energy use $[19,20]$.

A high-yielding crop takes up large quantities of potassium to cover its requirements during the whole vegetation. The highest accumulation of potassium is generally attributed to root crops such as sugar beet and potato. In fact, the first one yielding at the potential level, i.e., $80 \mathrm{t} \mathrm{ha}^{-1}$, accumulates more than $400 \mathrm{~kg} \mathrm{~K} \mathrm{ha}^{-1}$ [21]. Cereals are considered as low K consumers. Winter plants yielding at the level of $10 \mathrm{t} \mathrm{ha}^{-1}$, can accumulate at harvest $190 \mathrm{~kg} \mathrm{~K} \mathrm{ha}^{-1}$ [22]. It is necessary to stress that the total amount of $\mathrm{K}$ in the crop at harvest is by $1 / 10$ to $1 / 3$ lower than its maximum during the growth season. This difference should be taken into account when calculating the $\mathrm{K}$ recommended rate.

Potassium management by a crop requires an insight into some canopy characteristics: i) quantity of accumulated nutrient, ii) absolute/relative uptake rate, iii) dynamics of nitrogen uptake. The first step in understanding $\mathrm{K}$ impact on a crop productivity is to define its sensitivity to K supply. The general trend of $\mathrm{K}$ accumulation during the life cycle of a crop can be described by the sigmoid-like curve (Fig. 2). The same patterns, as shown in Fig. 2, have been found for winter wheat [22, 23] and for oil-seed rape [24]. The well-defined maximum describes the date of the highest amount of $\mathrm{K}$ fixed by the canopy followed by a subsequent decrease during maturation. The second important information drawn from Fig. 2 refers to $\mathrm{K}_{\max }$. As a rule, $\mathrm{K}$ accumulation precedes the absolute rate of both dry matter and $\mathrm{N}$ accumulation. Based on the pattern of $\mathrm{N}$ and $\mathrm{K}$ in-season accumulation, it can be formulated a hypothesis, that $\mathrm{K}$ accumulated in excess during the vegetative part of the seed crop growth builds-up a nutritional buffer, supporting effective $\mathrm{N}$ use during the grain filling period. The best examples are cereals, for which the crucial stage of dry matter production occurs at the end of booting and during heading. This period is decisive for establishing both the number of ears and grains per ear. At these stages, cereals reach the top of $\mathrm{K}$ accumulation, which is conclusive for high-yield [22, 23, 25].

The dynamics of potassium uptake by a crop can be described using indices such as the absolute/relative rate of $\mathrm{K}$ accumulation (A/R-RKA). The first one is shown in Fig. 3 for sugar beet. This crop can keep the uptake rate at the level of 10 and $9 \mathrm{~kg} \mathrm{~K} \mathrm{ha-1} \bullet \mathrm{d}^{-1}$ for 7 and 17 consecutive days, respectively. Dynamics of $\mathrm{K}$ uptake coincides with the absolute rate of the root system extension, reaching top values at the period of maximum dry matter accumulation, both in leaves and roots [26]. In oil-seed rape dominates the same pattern of $\mathrm{K}$ and $\mathrm{N}$ uptake. The uptake rate of $\mathrm{K}$ during the period from the rosette stage up to flowering ranges from 3 to $7 \mathrm{~kg} \mathrm{~K} \mathrm{ha}^{-1} \bullet \mathrm{d}^{-1}$, reaching the maximum at booting [24, 27]. The same potassium 
accumulation course was found for winter wheat [23]. In this particular case, the highest accumulation rate of $\mathrm{K}$ was lower than that observed for leafy crops, achieving 4.4 . $\mathrm{kg} \mathrm{K} \mathrm{ha}^{-1} \bullet$ $\mathrm{d}^{-1}$ from the beginning of stem elongation up to heading.

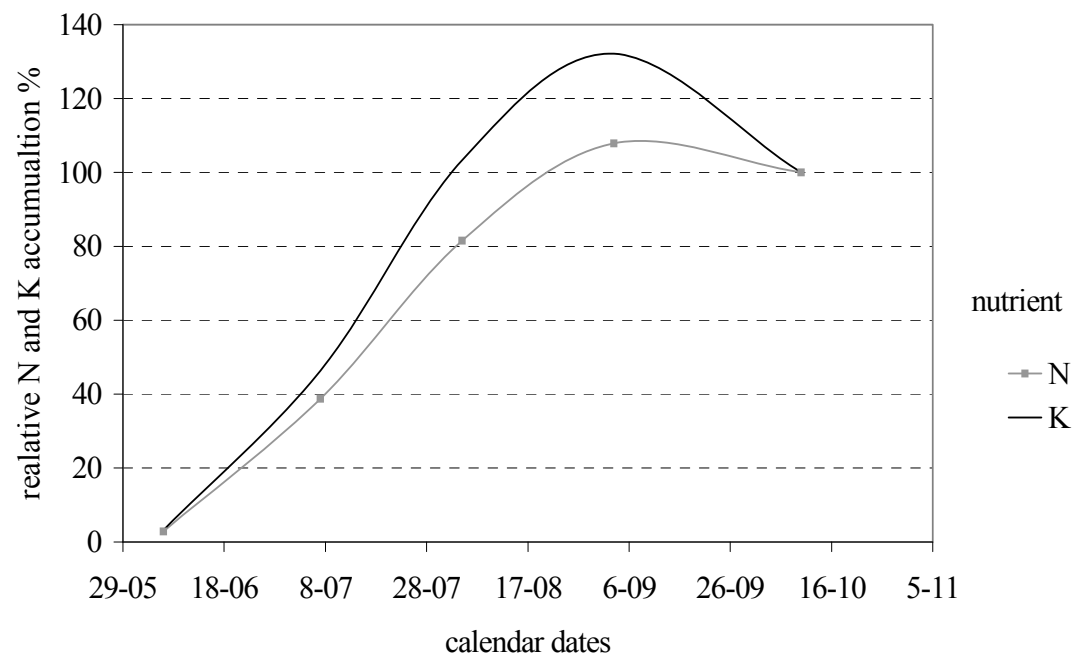

Figure 2. General pattern of $\mathrm{K}$ and $\mathrm{N}$ accumulation in high-yielding crops, a case of sugar beet; Source [21]

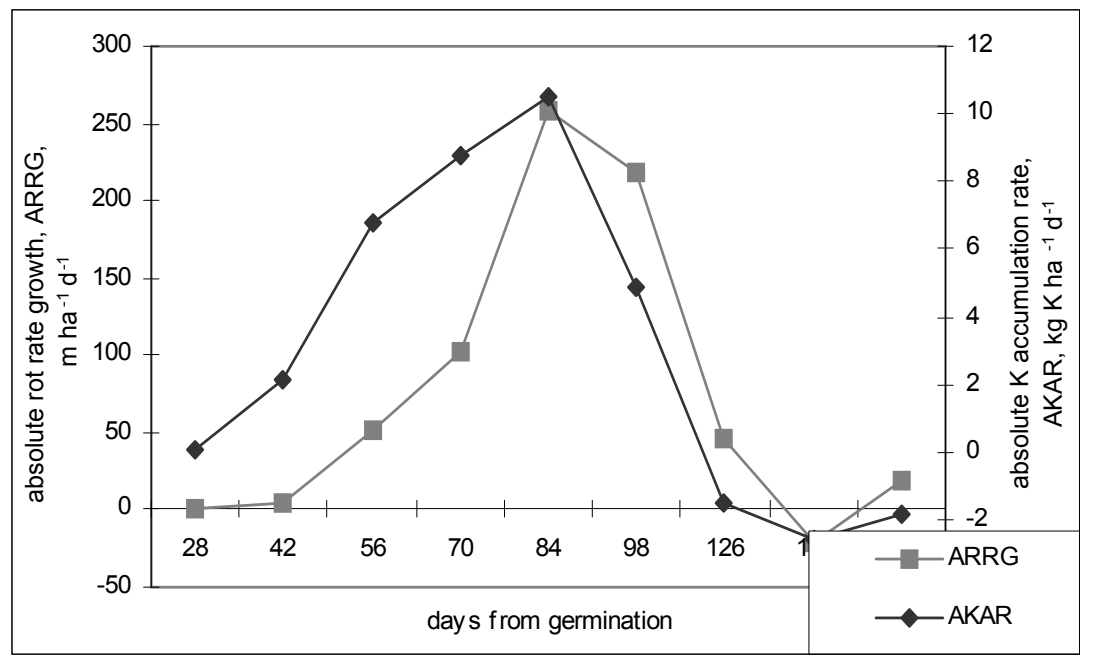

Figure 3. Dynamics of $K$ accumulation by sugar beet on the background of root growth; Adapted from [21, 28] 
Based on these sets of data it can be formulated a hypothesis that an efficient supply of potassium to a crop is a prerequisite of achieving the highest rate of canopy growth. The importance of potassium management for dry matter accumulation by a maize canopy is presented in Fig 4. The analysis of the course of crop growth rate (CGR) can be used to discriminate the critical stage of a particular crop response to the supply of potassium. In maize, for example, the elevated rate of dry matter accumulation takes place from tasselling (BBCH 51) and extends up to the blister stage (BBCH 71). This crop shows a very high plasticity to $\mathrm{K}$ management. The highest CGR was an attribute of both groups of plants grown on i) a fertile K soil, irrespectively on current K supply, and ii) medium $\mathrm{K}$ fertile soil but freshly fertilized with $\mathrm{K}$.

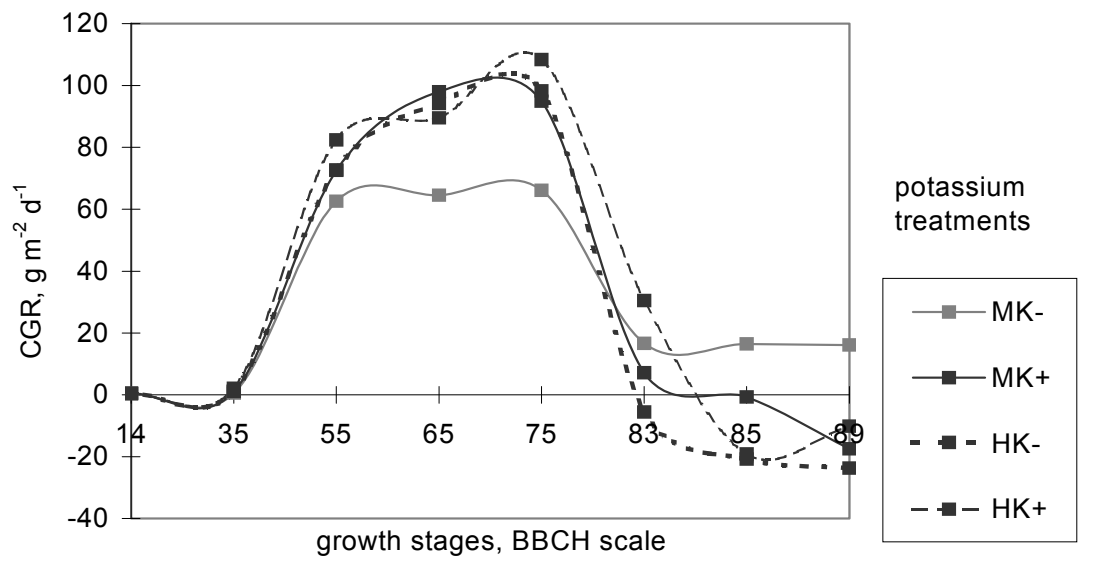

Legend: M, H - levels of soil fertility, medium and high, respectively; K-, K+ - freshly applied potassium; CGR - crop growth rate.

Figure 4. Dynamics of dry matter accumulation by maize on the background of potassium fertilizing; Source [29]

Plants take up potassium as the $\mathrm{K}^{+}$ions. Its availability and the plant uptake rate is affected by several soil and plant factors: i) K concentration in the soil solution, ii) size of the soil cation exchange complex, iii) soil properties such as: moisture, soil aeration and oxygen level, temperature, iv) plant crops internal requirements, v) rooting depth [30, 31]. The first two factors are decisive for potassium resources. However, $\mathrm{K}$ utility by a particular plant from different soil reservoirs depends on the internal plant requirement, which is defined by the rate of dry matter accumulation, expressed as the biomass ingrowths rate. In fact, it is the basic factor depending on the supply of water and nitrogen. Nevertheless, the evaluation of factor's hierarchy implicitly shows, that the rate of root growth affects the $\mathrm{K}$ uptake rate from soil resources the most [32]. The elucidation of the role of root growth requires a deep insight into mechanisms of potassium uptake by a plant root. Its has been well documented that $\mathrm{K}^{+}$ion's transportation from the soil solution to the root is mainly via diffusion. The movement of potassium depends on the water regime and plant root system activity [33]. The rate of any ion transportation to the root surface is governed by its effective diffusion 
rate $\left(D_{\text {eff }}\right)$, which is nutrient specific. Under constant physical conditions, ions with higher $\mathrm{D}_{\text {eff }}$ are taken faster, resulting in steeper depletion of its concentration in the bulk soil surrounding the root surface [34]. The occurring processes can be described quantitatively using the following set of equations:

$$
\begin{gathered}
d=\left(2 D_{\text {eff }} \times t\right)^{0.5} \\
D_{\text {eff }}=D_{w} \times \theta \times f / b \\
r_{1}=(4 / \pi)^{0.5} \times 1 /\left(\operatorname{Lv}_{\mathrm{r}} 0.5\right) \\
D d=\left(d / 0.5 r_{1}\right) \times 100 \%
\end{gathered}
$$

where:

$\mathrm{d}$ - the root depletion zone, $\mathrm{cm}$

$\mathrm{t}$ - time since initiation of calculation, days

$\mathrm{D}_{\text {eff }}$ - coefficient of diffusion in soil solution for a particular nutrient, $\mathrm{cm}^{2} \mathrm{~s}^{-1}$

$D_{w}$ - coefficient of diffusion in water for a particular nutrient, $\mathrm{cm}^{2} \mathrm{~s}^{-1}$

$\theta$ - volumetric soil water content, $\mathrm{cm}^{3} \mathrm{~cm}^{-3}$

$\mathrm{f}$ - tortuosity factor of soil pores, unitless

$\mathrm{b}$ - soil buffering capacity for a particular nutrient, unitless

$\mathrm{Lv}_{\mathrm{r}}$ - root length density, $\mathrm{cm} \mathrm{cm}^{-3}$

$\mathrm{r}_{1}$ - the mean distance between neighboring roots, $\mathrm{cm}$

Dd - degree of nutrient utility in the depletion zone, \%

The typical values of coefficients of diffusion for two main nutrients, i.e., nitrate nitrogen and potassium, are as follows: $210^{-6} \mathrm{~cm}^{2} \mathrm{~s}$ for nitrates and $210^{-7} \mathrm{~s}$ for potassium [35]. However, their values may significantly decrease under conditions of low water content down to $10^{-10}$ and $10^{-12}$ for both nutrients, correspondingly. The depletion zone calculated using typical values, and a period of seven days extends from the root surface to $18.5 \mathrm{~mm}$ and $4.9 \mathrm{~mm}$, respectively. It is necessary to keep in mind that the competition between two neighboring roots for a given nutrient begins, when their depletion zones overlap. Even though, the question remains, which nutrient is dominant in this process, in turn impacting the whole plant metabolism? Solving this problem requires sets of data concerning root length density, which is variable both between crop species, stage of development and root's distribution in the soil profile. Therefore, $\mathrm{K}$ uptake characteristics of winter wheat and sugar beets, were compared at stages with maximum uptake rates, i.e., at heading and in the second half of July, respectively (Table 2). The calculated half distance between neighboring roots, as a re- 
sult of root length density variability, increased with the soil profile depth. The degree of nitrate's utilization by wheat was the highest in the top-soil, several times exceeding its potential to deliver the required amount of nitrogen. The most spectacular is the fact that in the $7^{\text {th }}$-day period, the depletion of the nitrate-nitrogen zone extended down to $150 \mathrm{~cm}$. At the same time, the $\mathrm{K}$ depletion zone occurred at the depth of $60 \mathrm{~cm}$. In the case of sugar beet, the depletion zone for nitrates reached down to $90 \mathrm{~cm}$, whereas for potassium only to $30 \mathrm{~cm}$.

\begin{tabular}{|c|c|c|c|c|c|c|c|c|}
\hline \multirow{3}{*}{ Depth } & \multicolumn{4}{|c|}{ Winter wheat ${ }^{1}$} & \multicolumn{4}{|c|}{ Sugar beet ${ }^{2}$} \\
\hline & \multirow{2}{*}{$\begin{array}{c}\mathrm{Lv}_{\mathrm{r}} \\
\mathrm{cm} \cdot \mathrm{cm}^{-3}\end{array}$} & \multirow{2}{*}{$\begin{array}{l}\mathrm{r}_{1} \\
\mathrm{~cm}\end{array}$} & \multicolumn{2}{|c|}{$\mathrm{Dd}, \%$} & \multirow{2}{*}{$\begin{array}{c}\mathrm{Lv}_{\mathrm{r}} \\
\mathrm{cm} \cdot \mathrm{cm}^{-3}\end{array}$} & \multirow{2}{*}{$\begin{array}{l}\mathrm{r}_{1} \\
\mathrm{~cm}\end{array}$} & \multicolumn{2}{|c|}{ Dd, \% } \\
\hline & & & $\mathrm{NO}_{3}^{-}$ & $\mathrm{K}^{+}$ & & & $\mathrm{NO}_{3}^{-}$ & $\mathbf{K}^{+}$ \\
\hline $0-10$ & & & & & 2.7 & 0.73 & 509 & 134 \\
\hline $10-20$ & 8.2 & 0.42 & 888 & 234 & 3.1 & 0.68 & 546 & 144 \\
\hline $20-30$ & & & & & 2.1 & 0.83 & 449 & 118 \\
\hline $30-60$ & 1.7 & 0.92 & 404 & 106 & 0.38 & 1.95 & 191 & 50 \\
\hline $60-90$ & 1.0 & 1.20 & 310 & 82 & 0.26 & 2.35 & 158 & 42 \\
\hline $90-120$ & 0.7 & 1.43 & 259 & 68 & 0.08 & 4.24 & 88 & 23 \\
\hline $120-150$ & 0.27 & 2.31 & 161 & 42 & 0.01 & 12.00 & 31 & 8 \\
\hline $150-190$ & 0.03 & 6.93 & 54 & 14 & - & - & - & - \\
\hline
\end{tabular}

Adapted from ${ }^{1}[36]$ and ${ }^{2}[28]$

Table 2. Effect of root length density distribution in the soil profile on the degree of potassium and nitrate-nitrogen depletion at the critical stage of potassium accumulation by two crops

These two sets of data outline some important information concerning the management of both nutrients. Firstly, at the critical period of each crop development, nitrogen should be considered as a nutrient significantly limiting plant growth. In the case of wheat as a crop accumulating a significant amount of nitrogen in grain, an external supply of this nutrient is required at heading to fulfill this goal. A quite different strategy should be recommended for sugar beet, since it reaches at the critical stage of $\mathrm{K}$ accumulation maximum rates of both dry matter and nitrogen accumulation [26,37]. This crop in subsequent stages of growth relies on soil $\mathrm{N}$ resources, which uptake is governed by K supply. The second information refers to un-depleted resources of potassium, present in deeper soil layers. These reserves can be considered as the basic source of K supply during critical stages of beet growth and/or during any kind of growth disturbance due to stress. It is worth mentioning, that water shortages first limit nutrient flow in the topsoil, and then extend down the soil profile. Therefore, soil $\mathrm{K}$ reserves present in deeper soil layers are important for the exploitation of the plant yielding potential or to protect its growth under stress.

The effective transformation of solar energy into plant biomass depends on the supply of nitrogen, which is crucial for both carbon fixation and its subsequent partitioning among plant or- 
gans. Therefore, the rate of plant growth, taking into account its aerial part, is determined by nitrogen availability, especially nitrate ions. It is recognized, that higher soil moisture content usually means greater availability of nutrients to plants. Nitrogen supply to roots is via the transpiration stream of water (mass flow). Processes leading to the decrease of soil water content are the main reasons increasing the importance of diffusion as the core mechanism of nutrient transportation towards roots [30, 33, 38]. Nitrogen fertilizer use by a crop is related to the soil K fertility level. It has been documented, that insufficient supply of K results in lower, than expected, uptake rate of nitrate-nitrogen, which in turn decreases the rate of aerial biomass growth. This specific phenomenon is explained by the fact, that potassium accumulated at the root surface controls nitrogen inflow into the root. The rate of nitrate's transport through roots into the shoot depends on $\mathrm{K}$ concentration in the soil solution, governed also by K soil fertility level. At the same time, malate is produced in the shoot and part of the K-malate undergoes recycling through the root system [39]. Therefore, external and internal K sources are responsible for effective uptake of nitrogen from its soil pool. Insufficient supply of potassium from the soil solution significantly restricts the uptake of nitrates, reducing in turn their concentration in the root and consequently their transportation into leaves, where they undergo reduction. This also means, that the plant is not able to take up adequate amounts of $\mathrm{N}$, when $\mathrm{K}$ is in limited supply. It can be concluded, that high-yielding crops require excessive supply of $\mathrm{K}$ in order to match their demand for $\mathrm{N}$ in critical stages of yield component's development.

\section{Potassium as a water-stress ameliorative agent}

\subsection{Plant growth stages - Yield forming function of potassium}

Yield can be defined as the end-product of yield component's expression of a particular crop during growth and development. According to the concept multiple limitation hypothesis [MLH, 17], water and nitrogen supply plays a decisive role in assimilates partitioning among main crop plant organs [40,41,42]. These two nutrients affect both the rate of dry matter accumulation and yield component's development. In order to understand their influence on the rate of dry matter accumulation of the yield, the whole life cycle of a crop can be divided into three main periods: i) yield foundation (YFP), ii) yield construction (YCP), iii) yield realization (YRP) [43]. The shortage of potassium can affect plant growth in each of the above indicated periods. The key problem remains, about how potassium improves yield forming effect of water and nitrogen?

Potassium concentration in plant biomass varies from 1 to $5 \%$ of dry matter weight. When soil potassium is deficient, plant growth is reduced, resulting in smaller, dull bluish-green and wavy leaves and thinner stems. Plants often tend to wilt. Visual symptoms of potassium deficiency are easily recognized, but only those under severe potassium shortage, (Photo 1). In early stages of growth and also under hidden $\mathrm{K}$ deficiency, its visible symptoms are eventually confused with nitrogen deficiency. The main reason is the slow rate of the aerial biomass growth. The shortage of potassium is the reason of basic physiological processes disturbance, which in turn negatively affect the development of yield components. Potassi- 
um deficient plants: a) develop a weak root system, b) are not efficient in nitrogen uptake, c) grow slowly, d) develop infirm stems and lodges frequently, e) use inefficiently water and nitrogen, f) show high susceptibility to diseases, g) yield miserably, h) produce lower quality yield $[19,20]$. The recent study conducted in Canada showed that the shortage of potassium reduces grain of maize by $13 \%$ [44]. In the Central-Eastern European countries, during the last two decades, the supply of nitrogen has not been balanced with potassium and phosphorus, in turn seriously limiting harvested yields of cereals [45].

In the yield foundation period (YFP), K supply affects both the root system and aerial parts build up. In cereals, it stops at the end of tillering, and in all dicotyledonous crops, at the rosette stage. In general, at the beginning of the plant life cycle, the supply of water and nutrient is not considered as the factor limiting the root system extension. As a rule, all nutrients are uniformly distributed, and roots follow the genetically fixed patterns [30, 46]. Plants grown in soil fertilized with potassium, i.e., in the $\mathrm{K}$ fertile soil, show at early stages much higher rate of root system ingrowths. As a result, roots of plants well supplied with $\mathrm{K}$ are able to reach the deeper soil layers considerably earlier, than those poorly K-nourished. For example, the daily rate of extension of sugar beet roots, due to ample K supply can be accelerated by $50 \%$ as compared to plants grown in the $\mathrm{K}$ medium $\mathrm{K}$ level, irrespectively of the weather course. The same degree of maize response to high Kavailability has been documented. Cereals, for instance spring barley showed a much weaker response to the elevated K soil level [47]. The observed phenomenon supports the hypothesis, that Kinduces adaptation of crops to summer semi-drought, which emerges irregularly in temperate regions.

The key attribute of the yield construction period (YCP) is the linear rate of the dry matter increase. At the end of this period, crop plants reach the highest rate of growth. Therefore, K supply during this particular period is considered as the critical factor of yield performance. In cereals, it extends from the end of tillering up to the end of heading [48]. In other seed crops, the most sensitive phase to $\mathrm{K}$ shortage extends from the rosette up to the budding. Vegetable crops show sensitivity to K supply from the rosette up to technological maturity. For high-yielding crops, K supply is crucial for maximizing the dry matter accumulation and critical for yield component's development (Table 3). For example in maize, the shortage of potassium during anthesis negatively affects the number of kernels on the cob $[49,50]$. As shown in Table 4, plants grown on light soil showed poor development of this yield component, mainly due to the extremely strong response to drought in 2006. Therefore, any shortage of Kduring the linear period of each plant growth is considered as critical for final yield development.

The yield realization period (YRP) of a particular crop extends from the beginning of anthesis up to final maturity. The shortage of $\mathrm{K}$ affects the most vegetable crops, including potatoes. Seed crops are also sensitive to K supply during ripening, especially in regions of year-to-year weather variability. For example, the content of potassium in the flag leaf of winter wheat at the stage of milk grain maturity can significantly affect the yield (Y), as presented by the equation [51]:

$$
\mathrm{Y}=2.35 \mathrm{~K}+4.0 ; \mathrm{R}^{2}=0.75 \mathrm{n}=9 \text { and } \mathrm{P} \leq 0.01
$$




\begin{tabular}{|c|c|c|}
\hline Crop & Visual symptoms of deficiency & negatively responded component/parts \\
\hline Cereals & $\begin{array}{l}\text { dull green color; tip and marginal chlorosis on } \\
\text { lower leaves }\end{array}$ & $\begin{array}{l}\text { - number of ears per unit area, } \\
\text { - grains per ear }\end{array}$ \\
\hline Maize & $\begin{array}{l}\text { curling of leaves by mid-morning, tip and } \\
\text { marginal chlorosis on lower leaves }\end{array}$ & $\begin{array}{l}\text { - number of kernel's rows, } \\
\text { - number of kernels per row }\end{array}$ \\
\hline Oil-seed rape & $\begin{array}{l}\text { smaller rate of rosette growth, } \\
\text { tan-coloring of lower leaves }\end{array}$ & $\begin{array}{l}\text { - secondary branches, } \\
\text { - capsules per branch }\end{array}$ \\
\hline Sugar beet & $\begin{array}{l}\text { early leaves wilting during heat of the mid- } \\
\text { day, tip and marginal chlorosis on older leaves }\end{array}$ & $\begin{array}{l}\text { - size of leaves, } \\
\text { - weight of storage root, } \\
\text { - content of sugar }\end{array}$ \\
\hline Potato & $\begin{array}{l}\text { wilting-like shape of canopy during heat of } \\
\text { the mid-day, tip and marginal chlorosis on } \\
\text { older leaves }\end{array}$ & $\begin{array}{l}\text { - number of stems, } \\
\text { - weight of tubers, } \\
\text { - content of starch }\end{array}$ \\
\hline
\end{tabular}

Table 3. Effect of potassium deficiency during the linear period of crops growth on visual symptoms and yield components development

\begin{tabular}{|c|c|c|c|c|c|c|c|c|c|}
\hline \multirow{3}{*}{$\begin{array}{l}\text { Experimental } \\
\text { factor }\end{array}$} & \multirow[t]{3}{*}{ Level of factor } & \multicolumn{8}{|c|}{ Yield and elements of yield structure } \\
\hline & & \multicolumn{2}{|c|}{ Yield, $\mathrm{t} \mathrm{ha}^{-1}$} & \multicolumn{2}{|c|}{$N_{K} R^{3}$} & \multicolumn{2}{|c|}{ NKC } & \multicolumn{2}{|c|}{ TGW, $\mathrm{g}$} \\
\hline & & $L^{1}$ & $\mathbf{M}^{2}$ & $\mathbf{L}$ & M & $\mathbf{L}$ & M & $\mathbf{L}$ & M \\
\hline \multirow{4}{*}{$\begin{array}{l}\text { Fertilizing } \\
\text { treatments }\end{array}$} & NP & $6.49^{a}$ & $8.27^{\mathrm{a}}$ & $24.9^{a}$ & $26.8^{a}$ & $357^{a}$ & $390^{a}$ & $239^{a}$ & $259^{a}$ \\
\hline & NPK & $7.05^{b}$ & $9.61^{b}$ & $26.3^{\mathrm{a}}$ & $29.2^{b}$ & $376^{a}$ & $421^{b}$ & $251^{a b}$ & $284^{b}$ \\
\hline & NPKMgS & $7.46^{b}$ & $10.1^{b}$ & $26.3^{a}$ & $29.1^{b}$ & $370^{a b}$ & $411^{a b}$ & $261^{b}$ & $306^{c}$ \\
\hline & NPKMgSNa & $7.35^{b}$ & $10.6^{c}$ & $24.6^{a}$ & $27.7^{a b}$ & $365^{a b}$ & $405^{a b}$ & $249^{a b}$ & $323^{d}$ \\
\hline \multirow[t]{3}{*}{ Years } & 2005 & $8.85^{b}$ & $10.3^{b}$ & $31.7^{b}$ & $27.0^{a}$ & $473^{b}$ & $410^{b}$ & $275^{c}$ & $301^{b}$ \\
\hline & 2006 & $2.73^{a}$ & $8.13^{a}$ & $14.3^{a}$ & $25.7^{a}$ & $159^{a}$ & $334^{a}$ & $217^{a}$ & $298^{b}$ \\
\hline & 2007 & $9.69^{c}$ & $10.5^{b}$ & $30.6^{b}$ & $31.9^{b}$ & $470^{b}$ & $476^{c}$ & $259^{b}$ & $277^{a}$ \\
\hline
\end{tabular}

Source [55]

ameans with the same letter are not significantly different at $a=0.05$ (Tukey test);

${ }^{1}$ L: light soil - loamy sand, ${ }^{2} \mathrm{M}$ : medium soil - sandy loam; ${ }^{2} \mathrm{NR}$ - number of rows per cob,

NKR - number of kernels per row, NKC - number of kernels per cob, TGW - thousand grain weight.

Table 4. Statistical evaluation of main factors affecting yield and structural components of maize grain yield at the background of soils differing in texture 
This finding corroborates the importance of the subsoil $\mathrm{K}$ reserves for efficient management of $\mathrm{N}$, as the nutrient decisive for leaves activity during ripening of cereals. The grain weight increase in response to $\mathrm{K}$ supply is probably related to its effect on assimilates transportation in the phloem [20]. Thousand-grain weight (TGW), a structural parameter of a grain yield of seed crops, indirectly describes a plant nutritional status in this period. The final weight of kernels generally reflects the crop canopy capability both to produce and to supply carbohydrates to growing kernels [52]. As presented in Table 4, this yield component showed a significant response to all studied factors, but the soil complex was the most important. Plants grown on soil, naturally reach in potassium, achieved TGW by $17 \%$ higher as compared to those grown on light soil, in spite of the same content of $\mathrm{K}$ initially available.

Water requirements of plant crops are variable accordingly to the stage of their growth. The most sensitive stages cover the linear phase of biomass accumulation [see equation No. 7]. Sugar beet and potato plants are responsive to water supply during the most of the season, but especially during the highest rate of the dry matter increase, i.e., in the mid-season (July and August in the temperate regions of the world). Soil water capacity is a function of its textural class and precipitation over the whole season. It has been documented, that long-term fertilization with potassium results in increasing content of plant available water [47]. This phenomenon is probably explained by specific, glue-like action of potassium ions to individual soil grains [53]. The spatial pattern of water uptake from various regions of the soil profile depends on both soil moisture and roots distribution [46]. Water uptake and extraction patterns are related to rooting density. For example, a high-yielding winter wheat extracts 50 to $60 \%$ of total water from the first $0.3 \mathrm{~m} ; 20$ to $25 \%$ from the second $0.3 \mathrm{~m} ; 10$ to $15 \%$ from the third $0.3 \mathrm{~m}$ and less than $10 \%$ from the fourth $0.3 \mathrm{~m}$ soil depth. The usability of water by plant root from deeper layers depends on its penetration ability [54]. However, the deepest parts of the soil profile are responsible for water and nitrogen supply during stages of maximum dry matter accumulation.

The maximum rate of water use by crop occurs at field capacity, i.e. at maximum soil available water content. As the soil dries, the attainable soil water content decreases, leading to a significant drop in plant water potential, which also depends on plant structure and transpiration rate. At the onset and during sustained periods of drought, highly synchronized responses occur between root and shoot tissues. Signals from the roots have almost immediate effects upon shoot growth and its physiological functions, which modify the crop plant response to drought, in turn its productivity. The prolonged drought disturbs the diurnal rhythm of stomata, which are not able to control water loss from the leaves, further increasing the stress. Next, photosynthesis rate declines and respiration tend to increase, reducing consequently, dry matter accumulation. Shortage of assimilates transport to roots decreases the rate of their growth and as a 
consequence root system may be less able to utilize reserves of water stored in deeper soil layers [38, 46, 56].

The main agronomic problem, but not only, is the question how the water deficit may be ameliorated? In agriculture practice irrigation and breeding used to be treated as the main ways for overcoming water shortages. The simplest solution is to supply more water, i.e., to irrigate. However, not all farmers can invest in irrigation equipments. The second solution is to find out varieties, well adapted to water shortage. So far, in spite of huge investigation, breeding for drought resistance, remains still the open-box [56, 57]. It is well known, that root morphology is guided genetically, but the ultimate shape of the root system largely depends on the effects of environmental factors. The depth of the soil reservoir that holds water available to a plant is, in fact, determined by plant's rooting, in turn depending on soil characteristics, including compacted layers and water storage. Hence, the extension of roots into deep soil layers is crucial for crop performance under limited water supply. Drought adapted plants are characterized by great and vigorous root systems [58]. Experimental studies conducted in England showed that winter wheat roots below $1 \mathrm{~m}$ contribute only to $3 \%$ of total root system weight, but at the same time it delivered $20 \%$ of the transpired water during dry periods [54].

Under field conditions, water availability and its supply to currently growing crops is year-to-year variable, in turn affecting seasonal yields variability. Therefore, yields harvested by farmers in good years, i.e., under relatively ample supply of water, are usually higher, expressing higher unit productivity of the applied nitrogen and vice versa. It is recognized, that plant growth is better maintained under stress if adequate amounts of nutrients are available throughout the growing season. The deficit of nutrients reduces the rate of metabolic processes in the plant, making energy transfer and other growth processes less efficient. The adequate, balanced supply of $\mathrm{N}, \mathrm{P}$, and $\mathrm{K}$ should meet crop requirements, keeping its healthy and vigorously throughout the growth season $[19,30$, 33]. This conclusion is corroborated by data presented in Table 4. In 2005 and 2007, favorable for maize growth, yields of plants fertilized with NPK were significantly higher compared with those fertilized only with NP, irrespectively on soil texture. In the extremely dry 2006 year, in spite of the same input of fertilizers and soil K fertility level, harvested yields were by $2 / 3$ and $1 / 4$ lower as compared to good years, respectively for loamy sand and sandy loam. Grain yield responded to applied nutrients, but it was non-significant on the light soil (Fig. 5). This example implicitly indicates on the importance of inherent soil $\mathrm{K}$ fertility in ameliorating water shortage, significantly affecting crop growth during the Yield Foundation Period (Table 4). It can be therefore concluded that on light soils (L), $\mathrm{K}$ application ameliorates mild but not severe stresses. Soil originated from loams (medium soils, M) are much more resistant to drought, allowing to take under control water stress, provided a well potassium management. 


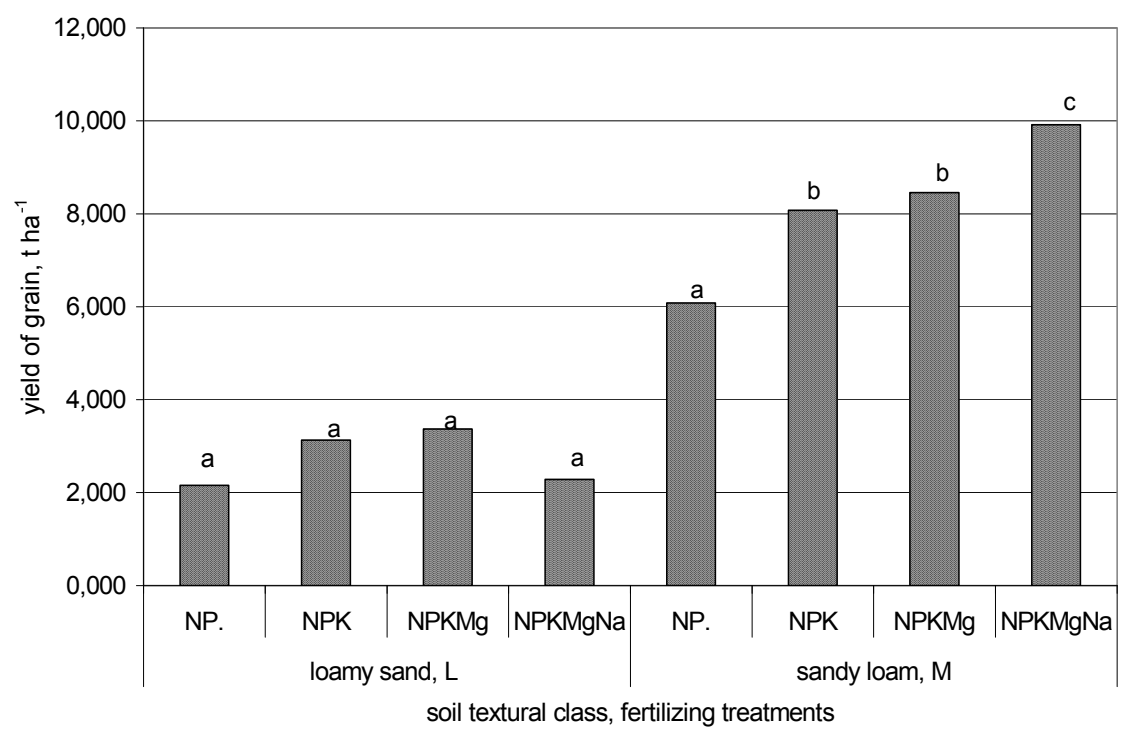

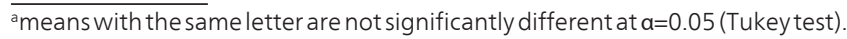

Figure 5. Response of maize grown on soil differing in texture to increased fertilization level in 2006 (dry year); Source [55]

\subsection{Impact of potassium on WUE - Maize as a case study}

The water-management index describing water-use efficiency (WUE) refers to the quantity of biomass produced by a crop plant per volume of water transpired and evaporated during its life cycle. In agronomy, the WUE index termed as the crop water productivity (CWP) relates the quantity of actually harvestable or marketable crop plant part (seeds, grain, roots, tubers, etc.) produced on a given area in a fixed period of time (yield, Y) per unit of transpired water [59]:

$$
\mathrm{CWP}=\mathrm{Y}_{\mathrm{a}} / \mathrm{ET}_{\mathrm{a}}
$$

The actual evapotranspiration $\left(\mathrm{ET}_{\mathrm{a}}\right)$ defines the amount of water use (transpired and evaporated water) $\left(\mathrm{mm}, \mathrm{m}^{3}\right)$ by the cultivated crop during its growth period. Its value is constant for a particular crop within a given geographical region, in spite of a slight year-to-year variability. For example, indices of $\mathrm{ET}_{\mathrm{a}}$ calculated for maize in two contrastive growth seasons 
2006 and 2007, with respect to the weather course, amounted to 622 and $572 \mathrm{~m}^{3}$, respectively (see Table 4). However, in 2006, harvested yields on light soil were much lower than on the medium one (Fig. 5). In contrast in 2007 yields were both considerably higher and did not show dependence on soil texture. Therefore, the applicability of the CWP index for evaluating yielding effects of agronomic factors is limited.

The French and Schulz approach, expressed as the water limited yield concept (WLYC), [60] is proposed [60] for the description of the impact of $\mathrm{K}$ on water management. The algorithm for the water limited yield (WLY) calculation is as follows:

$$
W L Y=T E\left(R+W R-\Sigma E_{s}\right)
$$

where: TE, maximum unit water productivity, fixed at the level of $20 \mathrm{~kg} \mathrm{ha}^{-1} \mathrm{~mm}^{-1}$, R refers to the sum of rainfall during the growth period, WR expresses water reserves in the soil profile down to $1 \mathrm{~m}$, and $\Sigma \mathrm{E}_{\mathrm{s}}$, represents the seasonal soil evaporation, equals to $110 \mathrm{~mm}$.

The proposed procedure takes into account two variables affecting WUE, resulting in yield fractionation. The first yield fraction (WLY), reflects a maximum yield at a given amount of attainable water to a crop during its growth. Controversies about the applicability of the Eq. No 9 refer mostly to the threshold value of the TE, which was originally set up for wheat at the level of $20 \mathrm{~kg}$ of grain per $1 \mathrm{~mm}$ of water [61]. In maize, taking into account its higher water-use efficiency, this threshold value is questionable and should be fixed at a slightly higher level. The another controversy refers to the importance of water reserves, WR, present in the soil profile. This water reservoir is responsible for both water, and nutrients supply at early stages of a plant growth. Therefore, this component of soil water characteristic has been introduced by Authors (the current chapter) into the original French and Schulz equation. The second yield fraction quantifies the net effect of the applied agronomic measure on WUE, resulting in yield gain or loss.

The graphical interpretation of the WLY concept, as proposed by Authors, allows to discriminate the effects resulting from the action of transpired water and that of the tested factor. As shown in Fig. 6, the maximum yield of maize was higher in the favorable year 2001 as compared to the dry one, i.e., 2003. The effect of increasing nitrogen rates was dependent on potassium management. In the treatment without $\mathrm{K}$ application, the highest yield increase due to $\mathrm{N}$ was documented for its rate of $100 \mathrm{~kg} \mathrm{ha}^{-1}$. In contrast, on plots with current $\mathrm{K}$ application, the highest yields were harvested in the treatment with $140 \mathrm{~kg} \mathrm{~N} \mathrm{ha}^{-1}$, irrespectively of the season. The relative contribution of $\mathrm{K}$ application in the final yield, measured for this particular treatment, was $40 \%$ and $6 \%$ in 2001 and 2003, respectively. It can be therefore concluded, that the exploitation of maize potential significantly depends on the nitrogen rate, but adjusted for the $\mathrm{K}$ fertility level. Therefore, any inadequately recommended $\mathrm{N}$ rate can result in yield decrease in good years or even its depression in years with drought, as occurred in 2003 (Fig. 6) and in 2006 on the light soil (Fig. 5). 


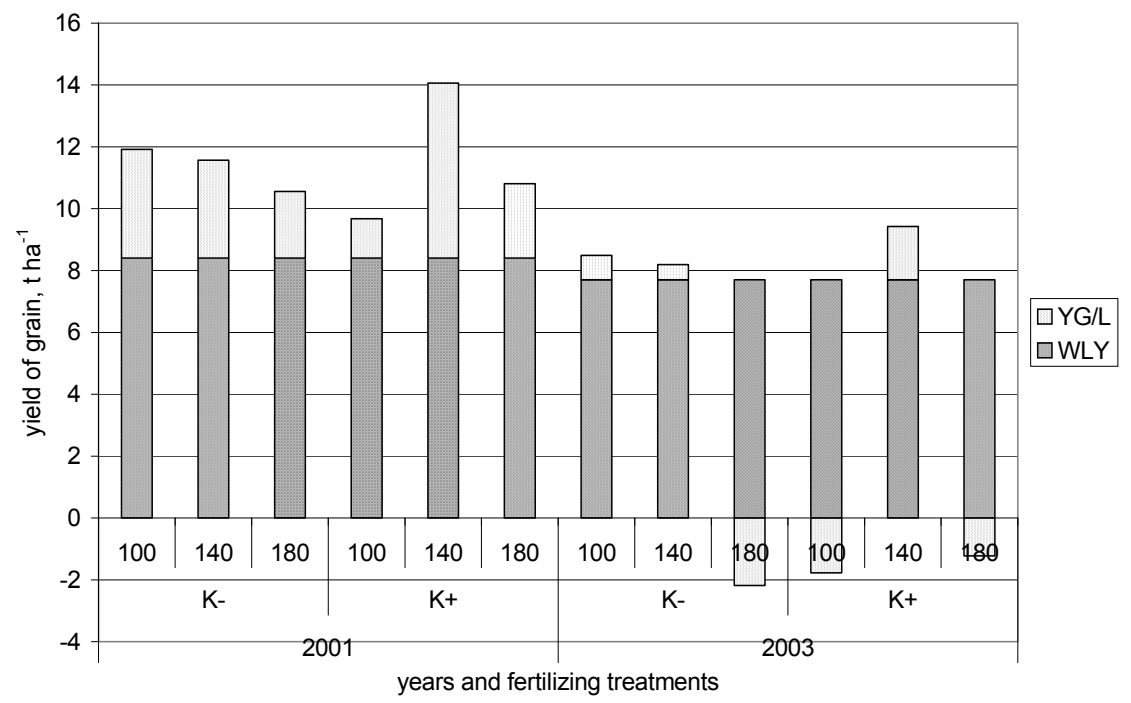

Legend: WLY - water limited yield; YG/YL - yield loss/gain, K-, K+ - K fertilizing treatments; 100, 140, $180 \mathrm{~kg} \mathrm{~N} \mathrm{ha-1}^{-1}$

Figure 6. Effect of soil K fertility level on maize yield in two weather contrastive years; Adapted from [62].

\section{Soil potassium resources $-K$ availability to crop plants}

\subsection{Soil K mining}

As described in the first part, the consumption of $\mathrm{K}$ fertilizers in many parts of the world has significantly decreased. The annual shortage of $\mathrm{K}$ in the global scale is calculated at the level of $20 \mathrm{~kg} \mathrm{ha}^{-1}$ [63]. Decades of cropping without sufficient replacement of $\mathrm{K}$ removed by harvested plant portions depleted soil $\mathrm{K}$ resources to the yield-limiting level. The long-lasting negative $\mathrm{K}$ balance is nowadays considered as the second factor of agricultural soil productivity degradation, following soil acidity. On the average, $18.6 \%$ world soils is extremely poor in potassium. The worst situation occurs in South-East Asia (43.5\%), followed by Latin America (39.3), Sub-Saharan Africa (29.7\%), East Asia (19.8\%) [64]. Central Europe and countries originated from Former Soviet Union are also threatened by soil mining, because $25 \%$ of arable soils present low content of potassium [65].

A minimum of $300 \mathrm{~kg} \mathrm{ha}^{-1}$ of available potassium is required for a good growth of highyielding crops, assuming 33\% of its utilization by crop [66]. In low-input systems, crop pro- 
duction mostly relies on soil resources and alternative sources of nutrients, including $\mathrm{K}$ mineral fertilizers. The high-input systems, which do not cover, or even replenish plant $\mathrm{K}$ needs at critical stages of yield development, result in soil K mining. High year-to-year variability and/or yields stagnation is not always recognized as the attribute of the inappropriate $\mathrm{K}$ management. Therefore, all potassium mined soils as well as light textured and also organic soils should be considered as risky for crop production. For all these groups, recommended rates of applied $\mathrm{K}$ should be greater than its removal.

\subsection{Soil K pools}

The total content of soil potassium in the top-soil (layer 0-0.2 $\mathrm{m}$ ) ranges, depending on soil texture from ca 1000 to $50000 \mathrm{~kg} \mathrm{~K} \mathrm{ha}^{-1}$ [67]. Therefore, it can be concluded, that whole reserves of $\mathrm{K}$ in the rooted soil profile (down to $1.0 \mathrm{~m}$ ) are several times larger. However, most of the soil potassium is not directly attainable for currently growing crop. Soil $\mathrm{K}$ resources are distributed in pools, which release $\mathrm{K}^{+}$ions with different rates, depending on geochemical characteristics of a particular pool. Based on chemical extraction procedures and probability of K uptake by a meanwhile grown crop, four operational K pools/forms have been defined: i) water-soluble (WSK) ii) exchangeable (EXK), iii) non-exchangeable (NEXK, iv) structural/mineral (MIK). The first one, containing $\mathrm{K}^{+}$ions present in the soil solution, is directly available to the plant. In Polish soils, it content ranges from about 60 to $90 \mathrm{~kg} \mathrm{~K} \mathrm{ha}^{-1}$ for the light and heavy soil, respectively (Fig. 7]. This form of potassium is at its highest level in spring and decreases throughout the growth season as plant takes it up. It covers plant needs at early stages of growth, but not in the high-season. This K pool is also sensitive to leaching, which in temperate regions of the world takes place in autumn and winter, provided water saturation of the whole soil profile. The amount of leached $\mathrm{K}$ is inversely related to soil texture, ranging from 1 to $8 \mathrm{~kg} \mathrm{~K} \mathrm{ha}^{-1}$ for soil originated from loams and sands, respectively [66].

The second $\mathrm{K}$ pool (EXK) contains $\mathrm{K}^{+}$ions held by negatively charged clay and humus particles. In Polish soils, the amount of the EXK ranges from about 200 to $650 \mathrm{~kg} \mathrm{~K} \mathrm{ha}^{-1}$, for very light and heavy soils, respectively. For this $\mathrm{K}$ form a threshold content is fixed at the level of $100 \mathrm{mg}$ $\mathrm{kg}^{-1}$ [67], i.e., $360 \mathrm{~kg} \mathrm{~K}_{2} \mathrm{O}$ ha $^{-1}$. The first two $\mathrm{K}$ pools are in a dynamic equilibrium, enforced by the presence of the plant root. According to the Le Chatelier-Braun principle of contrariness, any changes in $\mathrm{K}^{+}$ions concentration in the soil solution results in their movement from the exchangeable to the soil solution pool. The reverse process occurs in response to K fertilizer's application. Both pools, when not replenished with $\mathrm{K}$ in fertilizers or manures, undergo depletion, decreasing the capacity to match plant demand in time and space $[68,69]$. Under lack and/or insufficient $\mathrm{K}$ delivery from external sources to currently grown crop, which even in the high cropping systems is not exception, but a rule, its growth and productivity depends on the non-exchangeable soil resources (NEXK). This pool is several times larger than the EXK one, as shown in Fig. 7. For this $\mathrm{K}$ form, the threshold level Is fixed at $400 \mathrm{mg} \mathrm{kg}^{-1}$ [70], i.e., 1440 $\mathrm{kg} \mathrm{K}_{2} \mathrm{O} \mathrm{ha}^{-1}$. The fourth pool (MIK) represents $\mathrm{K}$ in soil rocks and minerals. This pool is considered as long-term $\mathrm{K}$ reservoir, highly dependent on the type and the weathering rate of $\mathrm{K}$ bearing minerals [Table 5]. 


\begin{tabular}{|c|c|c|c|c|}
\hline Minerals ${ }^{1}$ & Formula & $\mathbf{g} \cdot \mathbf{k g}^{-1}$ & Rocks $^{2}$ & $\mathbf{g} \cdot \mathbf{k g}^{-1}$ \\
\hline K feldspar & $\mathrm{KAISi}_{3} \mathrm{O}_{8}$ & 140.3 & Sanstone & 12.3 \\
\hline Leucite & $\mathrm{KAISi}_{2} \mathrm{O}_{6}$ & 178.9 & Clays & 23.3 \\
\hline Nepheline & $(\mathrm{Na}, \mathrm{K}) \mathrm{AlSiO}_{4}$ & 130.0 & Shales & 20.4 \\
\hline Kalsilite & $\mathrm{KAISiO}_{4}$ & 246.8 & Limestons & 2.6 \\
\hline Muscovite & $\mathrm{KAl}_{3} \mathrm{Si}_{3} \mathrm{O}_{10}(\mathrm{OH})_{2}$ & 90.3 & Chernozem $^{3}$ & $8.4-22.0$ \\
\hline Biotite & $\mathrm{K}_{2} \mathrm{Fe}_{6} \mathrm{Si}_{6} \mathrm{Al}_{2} \mathrm{O}_{20}(\mathrm{OH})_{4}$ & 76.2 & Cambisols $^{3}$ & $11.4-20.9$ \\
\hline Phlogopite & $\mathrm{K}_{2} \mathrm{Mg}_{6} \mathrm{Si}_{6} \mathrm{Al}_{2} \mathrm{O}_{20}(\mathrm{OH})_{4}$ & 93.8 & Vertisols $^{3}$ & $16-28.5$ \\
\hline
\end{tabular}

Source ${ }^{1}[72],{ }^{2}[73],{ }^{3}[74]$

Table 5. Potassium content in K-bearing minerals ${ }^{1}$, rocks ${ }^{2}$ and soil ${ }^{3}$

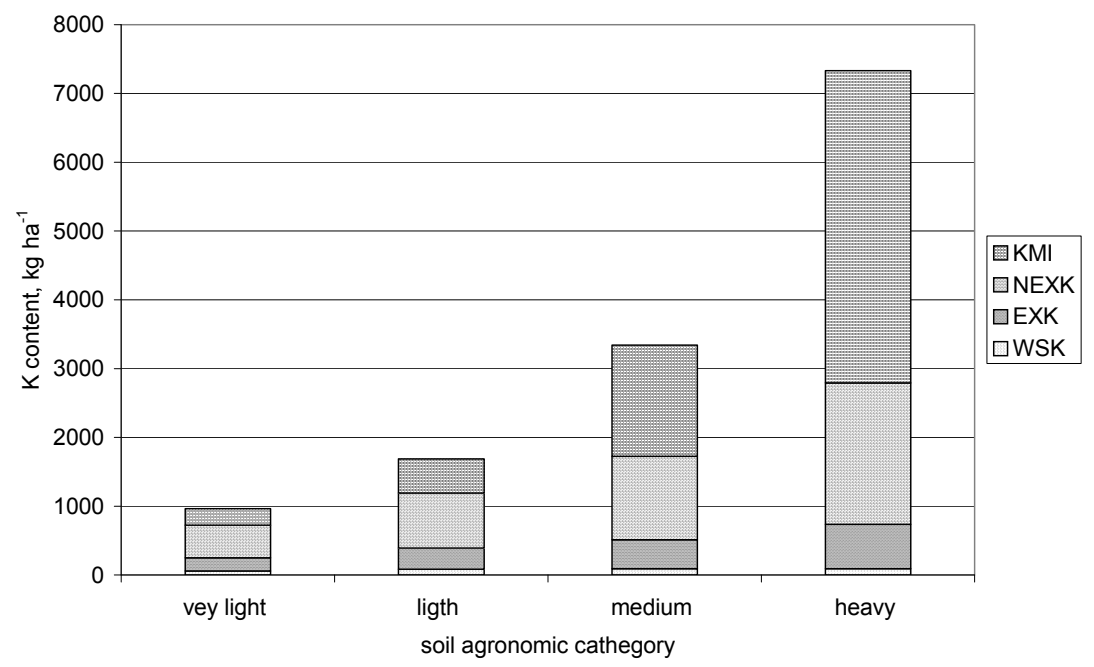

Figure 7. Distribution of potassium among pools in Polish soils at the background of soil texture; Adapted from [71]

\subsection{Factors affecting potential availability of the NEX-K to crops}

In the majority of cropping systems, harvested yields depend on the non-exchangeable $\mathrm{K}$ pool $[68,69]$. The yielding impact of this $\mathrm{K}$ form increases in most systems, where $\mathrm{K}$ removal by crop is not fully replenished. In order to elucidate the importance of this $\mathrm{K}$ pool for plant production, an example of four different fertilizing systems on spring barley yields is shortly described. The status of $\mathrm{K}$ forms in black earth after twelve cycles of three-course rotation, 
as presented in Table 6, showed a significant decrease in the content of both available and slow-released $\mathrm{K}$ forms. The EXK pool was much below the standards (100 mg K kg soils ${ }^{-1}$ ), irrespective of the fertilizing system. The NEXK was several times larger, exceeding the threshold level in three of four treatments, i.e., in K fertilized ones. The described study implicitly revealed the significant effect of the NEXK pool on yield of spring barley (Y):

$$
\mathrm{Y}=-0.456+0.008 \mathrm{NEXK} ; \mathrm{R}^{2}=0.69 ; \mathrm{n}=16
$$

In Poland, the official recommendation for $\mathrm{K}$ is based on the Egner-Riehm extraction procedure (Doppel-Lactat, $\mathrm{pH}$ 3.55). The harvested yield of barley grain also showed a significant dependence on the content of available K (ERK), following the quadratic model:

$$
\mathrm{Y}=-0.84+0.107 \mathrm{ERK}-0.00048 \mathrm{ERK}^{2} ; \mathrm{R}^{2}=0.55 ; \mathrm{n}=16
$$

This type of relationship between yield and available K means, that potassium supply limited the yield of grain to a certain value, which in this particular case was fixed at $111.5 \mathrm{~g} \mathrm{~K}$ $\mathrm{kg}^{-1}$ soil. This value implicitly indicates the FYM treatment as optimal for the maximum yield of barley. In the third step of evaluating the yield forming effect of $K$, the ERK was regressed against $\mathrm{K}$ content in other $\mathrm{K}$ pools. The applied stepwise regression implicitly revealed its significant dependence on the NEXK, The reliability of the ERK pool prediction was improved by implementing the EXK into the model:

$$
\begin{gathered}
\text { ERK }=-5.7+0.157 N E X K ; R^{2}=0.51 \text { and } P \leq 0.001 \\
\text { ERK }=-17.9+0.12 \text { EXK }+0.12 N E X K ; R^{2}=0.71 \text { and } P \leq 0.001
\end{gathered}
$$

\begin{tabular}{|c|c|c|c|c|c|}
\hline \multirow{3}{*}{$\begin{array}{l}\text { Potassium } \\
\text { treatments }\end{array}$} & \multicolumn{4}{|c|}{ K pools } & \multirow{2}{*}{$\begin{array}{c}\text { Egner-Riehm K } \\
\text { ERK }\end{array}$} \\
\hline & WSK & EXK & NEXK & MIK & \\
\hline & \multicolumn{5}{|c|}{$\mathrm{mg} \mathrm{kg}^{-1}$} \\
\hline Control & 7 & 17 & 378 & 1045 & 50 \\
\hline NPK & 16 & 33 & 648 & 949 & 84 \\
\hline FYM & 19 & 28 & 695 & 1140 & 114 \\
\hline $1 / 2 \mathrm{NPK}+1 / 2 \mathrm{FYM}$ & 10 & 33 & 565 & 855 & 61 \\
\hline
\end{tabular}

Source [68]

Table 6. Effect of 36 years of continuous fertilizing systems on the distribution of potassium forms 
The efficient use, i.e., exploitation of the non-exchangeable $\mathrm{K}$ pool in crop production requires to use specific agronomic methods. The most farming efforts are focused on increasing both amounts of plant available potassium and crop accessibility to this particular soil pool. There are numerous processes involved in the equilibrium between exchangeable potassium (EXK) and non-exchangeable potassium (NEXK) pools. The basic way in reaching both goals simultaneously is to fix the soil $\mathrm{pH}$ at a level adequate for the most sensitive crop in the crop rotation system. The application of lime induces a series of interrelated processes, resulting in the improvement of fundamental growth conditions for crop plants. Therefore, their demand for nutrients, including potassium, increases proportionately. Aluminum $\left(\mathrm{Al}^{3+}\right)$ neutralization is the primary effect of lime application, which in turn creates a chemical and physical milieu for better growth of roots. This action is the key agronomic practice responsible for increasing the accessibility of a given crop to potassium resources in the soil profile. Other processes induced by lime results in increasing amounts of available potassium in the soil solution. The key one is directly related to the disturbance of the $\mathrm{K}^{+} / \mathrm{Ca}^{2+}$ equilibrium at the interface soil solution/EXK pool. The sudden increase of $\mathrm{Ca}^{2+}$ ions concentration in the ambient soil solution is attributed to the accelerated rate of $\mathrm{K}^{+}$displacement from the cation exchange capacity (CEC). The another consequence of liming is the proliferation of soil fauna, which increases the rate of organic matter decomposition. The induction of microorganisms activity results in series of secondary processes affecting:

a. the release of $\mathrm{K}$ from organic matter,

b. the displacement of $\mathrm{K}^{+}$ions from both the EXK and NEXK pools,

c. the build-up of soil CEC,

d. the dissolution of non-exchangeable $\mathrm{K}$ from clay particles.

The processes reported in positions $a$ and $d$ are of a great importance for the current and long-term soil K economy, respectively. However, both are efficient the most under conditions of a slight acid $\mathrm{pH}$. At neutral $\mathrm{pH}$, the elevated concentration of $\mathrm{Ca}^{2+}$ slows down the effect of $\mathrm{H}^{+}$on $\mathrm{K}^{+}$displacement. With respect to the third process (position $c$ ), the build-up of soil organic matter content, oriented on increasing soil CEC is the long-term strategy of $\mathrm{K}$ management. The increased size of CEC should be considered as the extended reservoir for cations, both potentially threatened by leaching from the soil solution and/or dissolved from the non-exchangeable K pool.

In the last decade, a lot of scientific projects dealt with microorganisms, considered as a tool for increasing the availability of K from non-exchangeable potassium (NEXK) and that occluded in rocks and minerals (MIK) pools. The study carried out with plant growth-promoting Rhizobacteriaceae (PGPR) showed, that some bacterial strains such as Bacillus edaphicus, Bacillus mucilaginosus are capable to release potassium from silicate minerals. Their action in $\mathrm{K}$-bearing minerals is via $\mathrm{H}^{+}$ions, and/or by organic acids (citric, tartaric, oxalic), active in divalent cations complexion [72, 75, 76, 77]. A similar effect is expected when plants such as cotton, grasses, legumes, crucifers were used. 
The importance of externally incorporated microorganisms to arable soil in raising up soil fertility as described above was mostly limited to laboratory experiments. The study conducted with the application of bio-fertilizers in Poland showed, in general, a significant increase of mineral nitrogen content, indirectly stressing on the accelerated rate of organic matter decomposition. Much larger amounts of released nitrates in response to increasing fertilizers application and bio-fertilizer indicate an efficient rate of ammonia nitrification, which in turn generates $\mathrm{H}^{+}$. The formulated hypothesis assumes a local soil acidification, which results in a significant increase of cations and phosphorus contents. The highest increase of the latter ones suggests a multifunctional action of soil applied microorganisms (Table 7).

\begin{tabular}{|c|c|c|c|c|c|}
\hline \multirow{2}{*}{ Treatments } & $\mathrm{N}-\mathrm{NH}_{4}{ }^{+}$ & $\mathrm{N}-\mathrm{NO}_{3}{ }^{-}$ & $\mathrm{P}_{2} \mathrm{O}_{5}$ & $\mathrm{~K}_{2} \mathrm{O}$ & $\mathrm{Mg}$ \\
\hline & \multicolumn{2}{|c|}{$\mathrm{kg} \mathrm{ha}^{-1}$} & \multicolumn{3}{|c|}{ mg kg soil ${ }^{-1}$} \\
\hline N & $24.3^{1}$ & $55.1^{1}$ & 36.2 & 91.6 & 76.6 \\
\hline $\mathrm{N}+$ biofertilizer & 26.6 & 72.1 & 59.2 & 111.7 & 97.0 \\
\hline NPK + biofertilizer & 28.4 & 107.4 & 91.5 & 140.4 & 88.9 \\
\hline
\end{tabular}

Source [78], 'extracted in $0.01 \mathrm{M} \mathrm{CaCl}_{2}$,

Table 7. Effect of a bio-fertilizer on the post-harvest content of available nutrients in soil cropped with potato'

\section{Crop rotation - The background of soil fertility management}

Crop rotation describes a sequence of crop plant species cultivated on the same field within a fixed time. Three classical principles of crop rotation include: i) an appropriate choice of cultivated species, ii) crop frequency, taking into account some biological limitation, iii) fixed crop sequence. Crop rotation, in fact, under a particular climate and soil agronomic properties of a field, defines the structure and management of applied inputs. The main goals of crop rotation are:

a. yield stability, as a basis of a long-term stabilization of farm economy,

b. amelioration of the resistance of growing plants to stress, mostly of biological origin,

c. optimization of the use of soil resources, with respect to water and nutrients.

All these goals were rigorously guarded by farmers up to the end of the first half of the XX century. The technical progress, which started at the beginning, but accelerated in the sec- 
ond half of the XX century, resulted in a great increase of agriculture means of production, including fertilizers and pesticides. In addition, for the period extending from 1950 to 1970, intensive breeding programs within the "Green Revolution" succeeded first in new wheat and rice varieties, and next other cereals and maize. The main attribute of high-yielding varieties at that time was the extended capacity to accumulate nitrogen. Soon, the rigid crop sequence rules, based on legumes as a source of nitrogen and assuring its biological protection became limiting factors in a sharp yield increase. Consequently, changes in sequences of cultivated crops practiced by farmers were more and more oriented on net income, neglecting at the same time the efficiency of applied nitrogenous fertilizers, pesticides. This in turn increased the pressure of agriculture on environment $[2,80,81]$.

New paradigms of agriculture development, oriented on sustainable use of resources, can be achieved, provided crop rotation rules are introduced. The modern view on principles of crop rotation arrangement takes into account its flexibility in the selection of crop species, depending on market needs. Nowadays, the objectives of the rational crop sequence should strictly consider i) the farm economic profitability - its adaptability to market oriented changes, ii) the optimization of resource use, both internal (soil) and external (fertilizers, pesticides), iii) the minimization of the impact of agriculture on local and global environment (nitrogen, phosphorus) [82,83]. Therefore, a profitable crop production requires the development of alternative strategies, oriented on a well-thought-out management of water and nutrient resources in a particular crop rotation.

The reported expectations and assumptions regarding crop rotation refer also to potassium management. There are some experimental data supporting the concept of sustainable use of soil potassium, based on crop rotation principles:

a. soil, taking into account the whole profile, must be sufficiently reach in $\mathrm{K}$ to supply sufficient amount of potassium to a high-yielding crop within an extremely short period of growth - the critical period of yield components formation, to assure maximization of its yielding potential exploration [21, 24],

b. leafy crops, for example sugar beet, oilseed rape, to cover $\mathrm{K}$ requirements during crucial stages of growth, need to explore a thick layer of the soil profile [28, 84],

c. root system of leafy crops is much weaker in comparison to cereals (Table 8), being a prerequisite of higher level of available potassium,

d. demand of cereals for potassium is much lower than leafy crops; root density is at the same time much higher, hence a higher efficiency in K uptake (Fig. 8; Table 8),

e. both leafy crops and cereals respond more to soil fertility K level than to freshly applied fertilizer K $[27,66,85,86]$,

f. all crops respond to current potassium fertilization in years with stress, mostly related to water shortage and site specific diversification of $\mathrm{K}$ management $[47,55,86,87]$. 


\begin{tabular}{lcc}
\hline Crops & $\mathbf{R L}_{\mathbf{v}}, \mathbf{c m ~ \mathbf { ~ c m } ^ { - 3 }}$ & $\mathbf{R}_{\mathbf{d}} \mathbf{c m}$ \\
\hline Been & $0.5-2.0$ & 0.50 \\
\hline Oil-seed rape & - & 1.00 \\
\hline Potato & $1-2$ & 0.50 \\
\hline Sugar beet & $1-2$ & 1.00 \\
\hline Barley & $3-4$ & 0.50 \\
\hline Wheat & $3-8$ & 0.80 \\
\hline Rye & $4-8$ & 1.00 \\
\hline
\end{tabular}

Source ${ }^{1}[88],{ }^{2}[89]$

Table 8. Root length density $\left(R L_{V}\right)^{1}$ in the top-soil layer and mean rooting depth $R_{d}{ }^{2}$

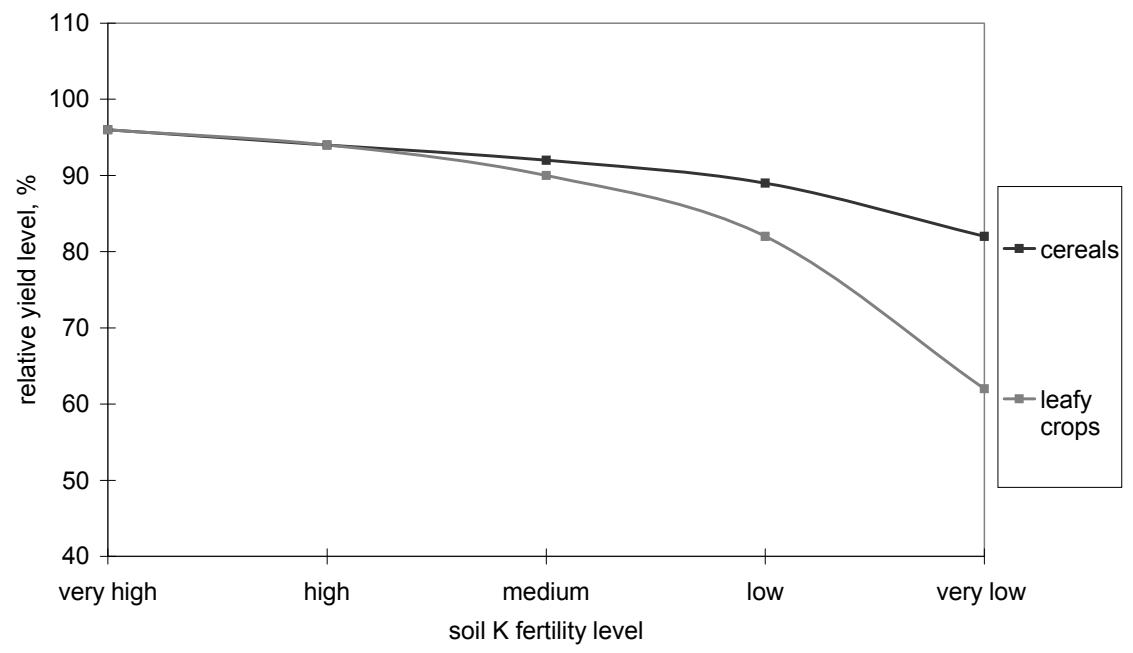

Figure 8. Effect of soil potassium fertility level on yield level of two groups of crop plants; Adapted from [90]

\section{Crop rotation potassium balance - A strategic scale of $\mathrm{K}$ management}

\subsection{System of potassium fertilization - Key assumptions}

The efficient system of potassium management should focus on requirements of the most sensitive crop in a particular crop rotation. The mandatory objective of effective 
strategy of any crops fertilization with potassium is to cover $\mathrm{K}$ demands of the currently growing crop during the period of their highest growth rate. However, crop plants grown in a fixed crop rotation present different sensitivity to current level of attainable soil K. Thereby, the primary objective of rational K management should focus on fulfilling the requirements of the most sensitive crop within the given crop sequence. It demands for $\mathrm{K}$ determines the top level of the critical range of soil available $\mathrm{K}$ for the whole sequence of growing crops. The basic target is the non-limited supply of soil potassium to plants during stages of the highest biomass increase, which coincides with the end of the linear period of dry matter accumulation. The degree of the $\mathrm{K}$ requirement covering by the most sensitive crop is decisive for both: i) water-use efficiency, ii) nitrogen utilization use efficiency. Any increase of these two indices results in the degree of yield component's development, considered as a crucial for a yield increase. The secondary objective is to select production measures essential for reaching the required level of available $\mathrm{K}$ [66].

In general, the crop-oriented $\mathrm{K}$ fertilizing strategy relies on the view that crops such as sugar beet, potato, oil-seed rape, (grain) legumes are significantly more sensitive to K supply than cereals, when grown subsequently in a fixed crop rotation. Therefore, the economically successful and environmentally sound $\mathrm{K}$ fertilization system should based on five pillars, assuming that leafy crops:

a. are grown in rotation with other crops, mostly with cereals,

b. have a substantially weaker root system as compared to cereals,

c. express considerably higher quantitative requirements for $\mathrm{K}$ at critical stages,

d. can explore a thick volume of the soil profile,

e. are, in consequence, much more than cereals sensitive to the level of available soil $\mathrm{K}$.

The crop rotation-oriented strategy of $\mathrm{K}$ management also assumes a maximized recycling of internal, i.e., soil available $\mathrm{K}$ sources and field resources (plant residues). Therefore, the amounts of fertilizer $\mathrm{K}$ needed to cover its losses due to exports from the field in harvested products or/and leaching processes, depend also on the management of crop by-product (residues). The mentioned concept is in accordance with the Ideal Soil fertility (ISF) approach [91]. Potassium timing seems to be of secondary importance taking into account the strategic goals of $\mathrm{K}$ management. Natural growth conditions, mostly related to stressing factors, can only modify potassium fertilizer timing.

\subsection{Potassium balance sheet in crop rotation - An operational procedure}

Following the theoretical assumptions it appears that the main problem of adequate fertilization of the leafy crop with potassium is to develop an appropriate system of managing the potassium rotation-oriented system. The principal farmer's question is, how to achieve the target Kavailability range? The efficient K system development may consist of three basic steps:

a. preparation of the $\mathrm{K}$ balance sheet for all crops in the fixed cropping sequence, 
b. determination of the current level of available K,

c. correction of the current $\mathrm{K}$ level.

In practice, the balance sheet operates on the equation, which in a simple way quantifies $\mathrm{K}$ processes occurring at the field level:

$$
\mathrm{K}_{\mathrm{up}}+\mathrm{K}_{\mathrm{plr}}+\mathrm{K}_{\mathrm{nl}}=\mathrm{K}_{\mathrm{ni}}+\mathrm{K}_{\mathrm{fym}}+\mathrm{K}_{\mathrm{f}} \quad\left[\mathrm{kg} \mathrm{K}_{2} \mathrm{O} \cdot \mathrm{ha}^{-1}\right]
$$

Rearrangement of the equation No. 14 allows to calculate the potassium application rate:

$$
\mathrm{K}_{\mathrm{f}}=\left[\mathrm{P}_{\mathrm{up}} \pm \mathrm{P}_{\mathrm{plr}}+\mathrm{K}_{\mathrm{nl}}\right]-\left[\mathrm{K}_{\mathrm{ni}}+\mathrm{K}_{\mathrm{fym}}\right] \pm \mathrm{dK} \text { av } \quad\left[\mathrm{kg} \mathrm{K}_{2} \mathrm{O} \cdot \mathrm{ha}^{-1}\right]
$$

where:

$\mathrm{K}_{\mathrm{up}}-\mathrm{K}$ uptake by the main yield, $\mathrm{kg} \bullet \mathrm{ha}^{-1}$

$\mathrm{K}_{\mathrm{plr}}-\mathrm{K}$ accumulation in plant residues, $\mathrm{kg} \bullet \mathrm{ha}^{-1}$

$\mathrm{K}_{\mathrm{nl}}$ - natural $\mathrm{K}$ losses (erosion, leaching), $\mathrm{kg} \bullet \mathrm{ha}^{-1}$

$\mathrm{K}_{\mathrm{ni}}$ - natural $\mathrm{K}$ input (dry and wet deposition), $\mathrm{kg} \bullet \mathrm{ha}^{-1}$

$\mathrm{K}_{\mathrm{fym}}-\mathrm{K}$ supply in organic manure, $\mathrm{kg} \bullet \mathrm{ha}^{-1}$;

$\mathrm{K}_{\mathrm{f}}$ - fertilizer $\mathrm{K}, \mathrm{kg} \bullet \mathrm{ha}^{-1}$

$\delta \mathrm{K}_{\mathrm{av}}$ - intended/required change of soil available $\mathrm{K}, \mathrm{mg} \mathrm{kg} \bullet$ soil $^{-1}$

In agronomic practice, some components of the $\mathrm{K}$ balance sheet such as natural input or losses may be omitted due to their minor importance as a source of $\mathrm{K}$. The minimal set of data required when constructing the balance sheet for a particular crop sequence is as follows (Table 9):

a. unit $\mathrm{K}$ uptake (specific $\mathrm{K}$ uptake) by each crop cultivated in a given rotation, i.e., $\mathrm{K}$ accumulation in the main crop product unit and its respective amounts in the by-products, for example, in straw (expressed in $\mathrm{kg} \mathrm{K}_{2} \mathrm{O} \bullet \mathrm{t}^{-1}$ of the main product,

b. crop sequence in the fixed crop rotation,

c. methods of a specific management of by-products at the farm,

d. type of farm (crop, dairy, mixed) as related to manure production.

The first parameter shows a certain level of variability, according to soil, crop and production technology. The critical issue of the proposed concept relates to the management of the $\mathrm{K}_{\mathrm{plr}}$ component of the Eq. No 15. All vegetative plant organs, such as straw or sugar beet tops, are very important sources of potassium. The environmentally and economically sound solution is to incorporate all harvested by-products into soil. 


\begin{tabular}{|c|c|c|c|c|c|c|}
\hline \multicolumn{2}{|c|}{ Components of balance sheet } & \multirow{3}{*}{$\begin{array}{l}\text { Yield } \\
t \bullet h^{-1}\end{array}$} & \multicolumn{4}{|c|}{ Management of plant residues } \\
\hline & & & \multicolumn{2}{|c|}{ exported from the field } & \multicolumn{2}{|c|}{ left at the field } \\
\hline & & & losses & input $^{4}$ & losses & input \\
\hline Crop & products & & & & & \\
\hline \multirow[t]{2}{*}{ Sugar beet } & storage roots $^{1}$ & 60 & 60 & - & 60 & - \\
\hline & tops + root residues ${ }^{2}$ & $10+1$ & $250+15^{3}$ & 13.5 & $250+15$ & 238.5 \\
\hline Spring & grain & 6.0 & 36 & - & 36 & - \\
\hline barley & straw + root residues & $6.0+1.8$ & $72+27$ & 24.0 & $72+27$ & 89.1 \\
\hline Oilseed & seeds & 4.0 & 40 & - & 40 & - \\
\hline rape & straw+ root residues & $10+2.8$ & $200+42$ & 37.8 & $200+42$ & 217.8 \\
\hline Winter & grain & 8 & 40 & - & 40 & - \\
\hline wheat & straw + root residues & $9+2.55$ & $126+38.3$ & 34.4 & $126+38.3$ & 147.9 \\
\hline \multicolumn{2}{|l|}{ Total } & - & 946.3 & 109.7 & 946.3 & 693.3 \\
\hline \multicolumn{2}{|c|}{ K net balance I } & - & -836.6 & & -253 & \\
\hline \multicolumn{2}{|l|}{ Manure } & $34.0^{5}$ & +214.4 & & 0.0 & \\
\hline \multicolumn{2}{|c|}{ K net balance II } & - & -622.4 & & -253 & \\
\hline \multicolumn{2}{|c|}{$\mathrm{K}$ fertilizer needs, $\mathrm{kg} \mathrm{K}_{2} \mathrm{O} \bullet \mathrm{ha}^{-1}$} & & 622.2 & & 253 & \\
\hline \multicolumn{2}{|c|}{$\mathrm{K}$ fertilizer needs, $\mathrm{kg} \mathrm{K}_{2} \mathrm{O} \cdot$ ha $^{-1} \cdot$ year $^{-1}$} & & 155.6 & & 63.25 & \\
\hline
\end{tabular}

${ }^{1}$ main product, fresh weight;

${ }^{2}$ root residues + stubble - sugar beets $\approx 5 \%$, cereals $\approx 15 \%$, oil-seed rape $\approx 20 \%$ DW of aboveground biomass;

${ }^{3}$ content of $\mathrm{K}$ in plant residues;

${ }^{4} \mathrm{~K}$ recovery from plant residues/manure in the four-course rotation $\approx 90 \%$; 5 fresh weight, $\mathrm{K}_{2} \mathrm{O}$ content $=7 \mathrm{~kg} \mathrm{t}^{-1}$.

Table 9. An example of potassium balance, the 4-course rotation, $\mathrm{kg} \mathrm{K}_{2} \mathrm{O} \bullet \mathrm{ha}^{-1}$

\subsection{Determination of optimum soil K level}

The efficient management of potassium in a given field depends on cultivated crop species and their cropping sequence. The main operational objective is to assess the degree of each crop sensitivity in the fixed rotation to the amount of soil available + fertilizer K. The graphical procedure of the optimum $\mathrm{K}$ range determination assumes, that the target crop shows the response to the applied potassium fertilizer, when soil $\mathrm{K}$ supply is too low to harvest $95 \%$ of the maximum yield. Based on data obtained from on-farm experiments and farmers experiences, it is possible to determine the perfect range of available K. As presented in Fig. 9, the applied statistical procedure, specifically the linear-plateau and quadratic regression models, allowed to fix the critical $\mathrm{K}$ point (limit), amounting to $170 \mathrm{mg} \mathrm{K}_{2} \mathrm{O} \mathrm{kg}^{-1}$. However, as resulted from the analysis of the quadratic model, yield of the tested crop increased further up to $250 \mathrm{mg} \mathrm{K}_{2} \mathrm{O} \mathrm{kg}{ }^{-1}$ (Fig. 9). In the case of sugar beets, the ideal level of soil $\mathrm{K}$ has been fixed at high level (clearly defined range), irrespectively of the site (soil) and year. All other leafy crops also require a fixed, in general, high level of soil available $\mathrm{K}$ during critical stages of yield formation. This level of soil attainable $\mathrm{K}$ content is the basis of the needed 
rate of $\mathrm{K}$ supply to a crop during important stages of yield formation. For cereals, the required $\mathrm{K}$ level is much lower. In general, $100 \mathrm{mg} \mathrm{KEX} \mathrm{kg} \mathrm{soil-1}{ }^{-1} \mathrm{can}$ be considered as the upper range of this plant response to soil $\mathrm{K}$.

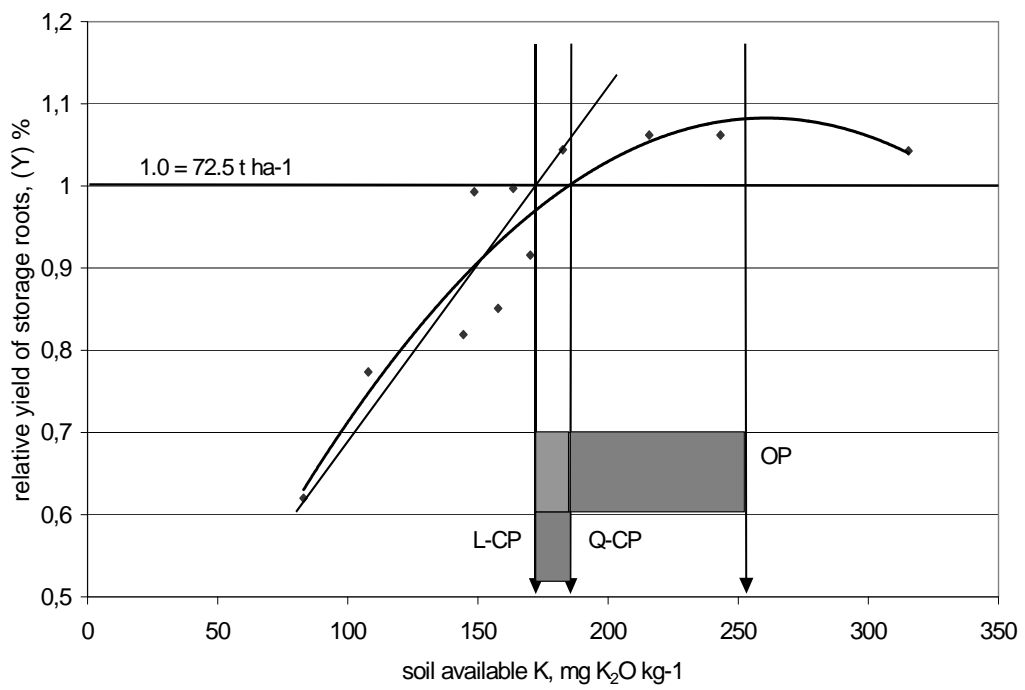

Legend: $\mathrm{L}-\mathrm{CP}, \mathrm{Q}-\mathrm{CP}$ - critical point (quantity of available $\mathrm{K}$ ) as determined by the linear $(\mathrm{L})$ and quadrate $(\mathrm{Q})$ regression models, respectively; OP- optimum content of available $\mathrm{K}$.

Figure 9. A graphical method of assessing the critical available soil $\mathrm{K}$ for reaching maximum yield of storage roots by sugar beet; Adapted from [92]

The annual loss of potassium from the cropped soil due to intended export or leaching ranges from about 20 to $33 \%$, depending on the crop [66]. Only in the case of leafy vegetable and fodder crops, its loss is substantially greater. Therefore, the required amount of potassium to be applied in rotation with leafy crops may be calculated using the equation No. 16. However, taking into account plant residues and their contribution to the required $\mathrm{K}$ amount, the needed quantity of purchased K fertilizer can be substantially, even by 3-times lower [Eq. No 17, Table 9]. Data concerning fertilizers value of crop residues can be obtained directly or calculated using constant relationships between K content in the main product and its concomitant by-product [66].

$$
\begin{gathered}
\mathrm{K}_{\mathrm{f}}=\left(\mathrm{K}_{\mathrm{ar}}-\mathrm{K}_{\mathrm{ca}}\right) \times 3 / 0.9\left[\mathrm{~K}_{2} \mathrm{O} \mathrm{ha}^{-1}\right] \\
\mathrm{dK}_{\mathrm{g}}=\mathrm{K}_{\mathrm{f}}=\left[\left(\mathrm{K}_{\mathrm{ar}}-\mathrm{K}_{\mathrm{ca}}\right) \times 3-\mathrm{K}_{\mathrm{rec}} / 0.9\left[\mathrm{~K}_{2} \mathrm{O} \mathrm{ha}{ }^{-1}\right]\right.
\end{gathered}
$$

where:

$\mathbf{K}_{\mathbf{f}}$ - potassium fertilizer rate, $\mathrm{kg} \mathrm{K}_{2} \mathrm{O}$ ha $^{-1}$ 
$\mathrm{K}_{\mathrm{ar}}$ - soil available $\mathrm{K}$ content required by the most sensitive crops in a fixed crop rotation, $\mathrm{mg} \mathrm{K}_{2} \mathrm{O} \mathrm{kg}{ }^{-1}$ soil, the critical range

$\mathbf{K}_{\mathrm{ca}}$ - current level of soil available $\mathrm{K}, \mathrm{mg} \mathrm{K}_{2} \mathrm{O} \mathrm{kg}^{-1}$ soil

$\mathrm{K}_{\text {rec }}-\mathrm{K}$ recycled in plant residues and/manure, $\mathrm{kg} \mathrm{K}_{2} \mathrm{O}$ ha-1

3 - coefficient for converting soil $\mathrm{K}$ into $\mathrm{K}$ rates.

It is possible, based on specific $\mathrm{K}$ requirements to assign all cultivated crops into a particular soil available K classes. This has been reported in Table 10 for key crops cultivated in Poland. By using this operational scheme, the farmer can define a right place for crops grown in a particular crop sequence with respect to the required level of soil available $\mathrm{K}$. This table can be considered as the first step in the development of the $\mathrm{K}$ fertilizing plan, oriented on $\mathrm{K}$ requirements of the most sensitive crop in the given crop sequence.

\begin{tabular}{|c|c|c|c|c|}
\hline \multirow{2}{*}{$\begin{array}{l}\text { Potassium } \\
\text { rating }\end{array}$} & \multicolumn{4}{|c|}{ Soil agronomic category } \\
\hline & Very light & Light & Medium & Heavy \\
\hline \multicolumn{5}{|l|}{ Very low } \\
\hline \multicolumn{5}{|l|}{ Low } \\
\hline \multicolumn{5}{|l|}{ Medium } \\
\hline \multicolumn{5}{|l|}{ High } \\
\hline Very high & & & & \\
\hline
\end{tabular}

the Egner-Riehm K extraction method

Legend: $\square$ low K sensitive crops: rye, oats, triticale

medium K sensitive crops:: wheat, barley, maize

high K sensitive crops vegetables, sugar beet, potatoes oil-seed raps, grain legumes

Figure 10 Critical ranges of available potassium ${ }^{1}$ for key crops in Poland

\section{Conclusion}

The modern nitrogen-oriented agriculture relies on mining of soil nutrient resources, mainly potassium. Therefore, its key attribute is low water- and nitrogen-use efficiency and high year-to-year variability of yields. Crop growth on soils poor in available potassium limits, consequently, food production in many regions of the world. Hence, the principal objectives of sustainable management of potassium are to: i) reduce year-to-year variability of harvested yields, ii) increase water- and N- use efficiency, iii) decreasing the pressure of agriculture on local and global environment. All applied agronomic measures should take into account $\mathrm{K}$ requirements of the most sensitive crop in a fixed crop rotation. Next, the required range of available $\mathrm{K}$ for the most sensitive crop, in turn should ensure effective $\mathrm{N}$ use during key stages of yield performance by all growing crops. The main way of fulfilling these goals is to gradually build-up or to re-build the attainable soil $\mathrm{K}$ pool. There are three key methods of economically profitable and environmentally sound $\mathrm{K}$ management. All of them rely on 
consecutive exploitation and use of: i) natural soil $\mathrm{K}$ reserves, ii) recycled organic $\mathrm{K}$ - plant residues, and in the last step, iii) $\mathrm{K}$ mineral fertilizers.

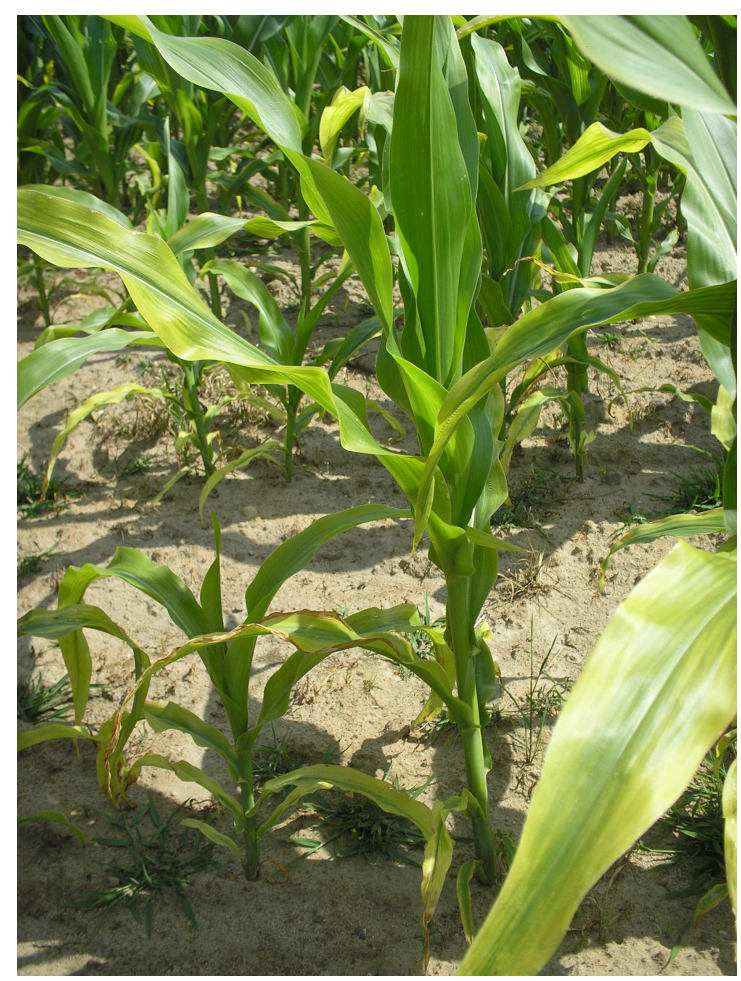

Photo 1. Potassium deficiency symptoms on maize; Author: Witold Grzebisz

\section{Author details}

Witold Grzebisz, Witold Szczepaniak, Jarosław Potarzycki and Remigiusz Łukowiak

Department of Agricultural Chemistry and Environmental Biogeochemistry, Poznan University of Life Sciences, Poland

\section{References}

[1] FAOSTAT. Available online at: http://faostat.fao.org/default.aspx. (accessed 2012-08-07). 
[2] Spiertz JHJ. Nitrogen, sustainable agriculture and food security: a review. In: Lichtfouse E, Navarrete M, Debaeke Ph, Véronique S, Alberola C. (eds.) Sustainable agriculture. Dordrecht: Springer Science+Business Media BV; 2009. p635-651.

[3] Eickhout B, Bouwman AF, van Zeijts H. The role of nitrogen in world food production and environmental sustainability. Agriculture, Ecosystems and Environment 2006; 116 4-14.

[4] Galloway J, Cowling E. Reactive nitrogen and the World: 200 years of change. Ambio 2002; 30 (2) 64-71.

[5] Kirchmann H, Thorvaldson G. Challenging targets for future agriculture. European Journal of Agronomy 2000; 12 146-161.

[6] Tait J, Morris D. Sustainable development of agricultural systems: competing objectives and critical limits. Futures 2000; 32 247-260.

[7] Groot JJR, Penning de Vries FWT, Uithol PWJ. Food supply capacity study at global scale. Nutrient Cycling in Agroecosystems 1998; 50 181-189.

[8] Pretty JN. The sustainable intensification of agriculture. Natural Resources Forum 1997; 21(4) 247-256.

[9] Wivstad M, Dahlin AS, Grant C. Perspectives on nutrient management in arable farming systems. Soil Use and Management 2005; 21 113-121.

[10] Lal R. Soils and food sufficiency: a review. In: Lichtfouse E, Navarrete M, Debaeke $\mathrm{Ph}$, Véronique S, Alberola C. (eds.) Sustainable agriculture. Dordrecht: Springer Science+Business Media BV; 2009. p25-49.

[11] Lal R. Soil degradation as a reason for inadequate human nutrition. Food Security 2009; $145-57$.

[12] Rabbinge R. The ecological background of food production. In: Crop protection and sustainable agriculture. Ciba Foundation Symposium 1993; 177222.

[13] Bindraban PS, Stoorvogel JJ, Jansen DM, Vlaming J, Groot JJR. Land quality indicators for sustainable land management: proposed method for yield gap and soil nutrient balance. Agriculture, Ecosystems and Environment 2000; 81 103-112.

[14] Evans L, Fisher R. Yield potential: Its definition, measurement and significance. Crop Science 1999; 39 1544-1551.

[15] Supit I, van Diepen C, de Wit A. Recent changes in the climatic yield potential of various crops in Europe. Agricultural Systems 2010; 103 683-694.

[16] Rabbinge R, Diepen C. Changes in agriculture and land use in Europe. European Journal of Agronomy 2000; 13, 85-100.

[17] Rubio G, Zhu J, Lynch J. A critical test of the prevailing theories of plant response to nutrient availability. American Journal of Botany 2003; 90(1) 143-152. 
[18] IFADATA. Available online at: http:// fertilizer.org/HomePage/STATISTICS. (accessed 2012-08-07).

[19] Cakmak I, Kirkby E. Role of potassium nutrition in growth and stress tolerance. Physiologia Plantarum 2008; V 133(4) 692-704.

[20] Marschner H. Mineral nutrition of higher plants. London: Academic Press; 1986.

[21] Grzebisz W, Barłóg P, Feć M. The dynamics of nutrient uptake by sugar beet and its effect on dry matter and sugar yield. Bibliotheka Fragmenta Agronomica 1998; 3(98) 242-249.

[22] Barraclough PB. The growth and activity of winter wheat roots in the field: nutrient uptakes of high-yielding crops. Journal of Agricultural Science Cambridge 1986; 106 45-52.

[23] Cannell RQ. Mitigation of soil constrains to cereal production. In: Gallagher ER. (Ed.). Cereal Production. London: Butterworths; 1984. p193-210.

[24] Barłóg P, Grzebisz W. Growth dynamics and nutrient uptake by winter oilseed rape fertilized with three types of nitrogenous fertilizers and a method of the second nitrogen rate division. Oilseed Crops 2000; XXI(1) 85-96 (in Polish with English summary).

[25] Zerche S, Hecht R. Nitrogen uptake of winter wheat during shoot elongation phase in relation to canopy high and shoot density. Agribiological Research 1999; 52(3/4) 231-250.

[26] Grzebisz W, Pepliński K, Szczepaniak W, Barłóg P, Cyna K. Impact of nitrogen concentration in sugar beet plant parts throughout the growing season on dry matter accumulation patterns. Journal of Elementology 2012; 17(3) 389-407.

[27] Orlovius, K. Results on oilseed rape fertilization with potassium, magnesium and sulfur in Germany. In: Grzebisz W. (ed.) Balanced fertilization of oilseed rape - current problems. Poznań: Agricultural University; 2000. p229-239 (in Polish with English summary).

[28] Windt A. Entwicklung des Faserwurzelsystems der Zuckerrübe sowie dessesn Beziehung zum Wachstum der Gesamtpflanze und der Nährstoffaufnahme. Göttingen: Cuvillier Verlag; 1995.

[29] Grzebisz W, Barłóg P, Szczepaniak W, Potarzycki J. Effect of potassium fertilizing system on dynamics of dry matter accumulation by maize. Fertilizers and Fertilization 2010; 40 57-69.

[30] King J, Gay A, Sylvester-Bradley R, Bingham I, Foulkes J, Gregory P, Robinson D. Modelling cereal root systems for water and nitrogen capture: towards an economic optimum. Annals of Botany 2003; 91 383-390. 
[31] Jung A, Classeen N. Availability in soil and acquisition by plants as the basis for phosphorus and potassium supply to plants. Zeitschrift für Pflanzenernährung und Bodenkunde 1997; 152 151-157.

[32] Barber SA. Potassium availability at the soil-root interface and factors influencing potassium uptake. In: Munson RD. (ed.) Potassium in Agriculture. Madison: SASCSSA-SSSA; 1985. p309-323.

[33] Kuchenbuch R, Classesn N, Junk A. Potassium availability in relation to soil moisture. I. Effect of soil moisture on potassium diffusion, root growth and potassium uptake of onion plants. Plant Soil 1986; 95 221-231.

[34] Nye PB, Tinker PH. Solute movement in the rhizosphere. New York: Oxford University Press; 2000.

[35] Pulford I, Flower H. Environmental chemistry at a glance. Oxford: Blackwell Publishing LtD; 2006.

[36] Claassen N, Steingrobe B. 1999. Mechanistic simulation models for a better understanding of nutrient uptake from soil. In: Mineral nutrition of crops. Zdenko Rengel (Ed.), 327-367.

[37] Szczepaniak W, Grzebisz W, Barłóg P, Cyna K, Pepliński K. Effect of differentiated fertilizing systems on nitrogen accumulation patterns during the growing season $-\mathrm{a}$ sugar beet example. Journal of Elementology 2012; 17 (4) (in press).

[38] Gonzalez-Dugo V, Durand JL, Gastal F. Water deficit and nitrogen nutrition of crops. A review. Agronomy for Sustainable Development 2010; 30 529-544.

[39] Marschner H, Kirkby EA, Cakmak J. Effect of mineral nutritional status on shoot-root partitioning of photo-assimilates and cycling of mineral nutrients. Journal of Experimental Botany 1996; 1255-1263.

[40] Agren GI, Franklin O. Root: shoot ratios, optimization and nitrogen productivity. Annals of Botany 2003; 92 795-800.

[41] Debaeke Ph, Aboudrare A. Adaptation of crop management to water-limited environments. European Journal of Agronomy 2004; 21 433-446.

[42] Lawlor DW. Carbon and nitrogen assimilation in relation to yield: mechanisms are the key to understanding production systems. Journal of Experimental Botany 2002; 53(370) 773-787.

[43] Sylvester-Bradley R, Lun G, Foulkes J, Shearman V, Spink J, Ingram J. Management strategies for high yields of cereals and oilseed rape. HGCA Conference: Agronomic Intelligence: the basis for profitable production, 16-17 January 2002, London, Great Britain, 2002.

[44] Subedi K, Ma B. Assessment of some major yield-limiting factors on maize production in a humid temperate environment. Field Crops Research 2009; 110 21-26. 
[45] Grzebisz W, Diatta J. Constrains and solutions to maintain soil productivity: A case study from Central Europe. In: Whalen JK.( ed.) Soil fertility Improvement and Integrated Nutrient Management - A Global Perspective. Rijeka: InTech; 2012. p159-182.

[46] Smucker AJM, Aiken RM. Dynamic root responses to water deficits. Soil Science 1992; 154(4) 281-289.

[47] Damm S, Hofmann B, Gransee A, Christen O. Zur wirkung von Kalium auf ausgewählte bodenphysikalishe Eigenschaften and den Wurzeltiegang landwirtschatlicher Kulturpflanzen. Archives of Agronomy Soil Science 2011; 1-19. DOI: 10.1080/03650340.2011.596827.

[48] Gäth, S., Meuser, H., Abitz, C-A., Wessolek. G., Renger/ M. (1989): Determination of potassium delivery to the roots of cereal plants. Zeitschrift für Pflanzenernährung und Bodenkunde; 152 143-149.

[49] D'Andrea K, Otequi M, Cirilo A. Kernel number determination differs among maize hybrids in response to nitrogen. Field Crops Research 2008; 105 228-239.

[50] Subedi K, Ma B. Nitrogen uptake and partitioning in stay-green and leafy maize hybrids. Crops Science 2005; 45 740-747.

[51] Grzebisz W, Musolf R, Szczepaniak W, Barłóg P. Effect of artificially imposed water shortages against a background of potassium supply on dry matter, nitrogen and potassium accumulation by winter wheat. Fertilizers and Fertilization 2009; 34 40-52.

[52] Pommel B, Gallai A, Coque M, Quillere I, Hirel B, Prioul J, Andrieu B, Floriot M. Carbon and nitrogen allocation and grain filling in three maize hybrids differing in senescence. European Journal of Agronomy 2006; 24 200-211.

[53] Soulié Fel, Youssoufi MS, Delenne JY, Voivret C, Saix C. Effect of the crystallization of a solute on the cohesion in granular materials. Powder Technology 2007; 17543 47.

[54] Gregory PJ, McGovan M. Biscoe PV. Water relations of winter wheat. 2. Soil water relations. The Journal of Agricultural Science, Cambridge 1978; 91 103-116.

[55] Szczepaniak W, Grzebisz W, Barłóg P, Przygocka-Cyna K. Response of maize varieties to increasing nutrient input on the background of natural soil fertility. Fertilizers and Fertilization 2010; 40 127-139.

[56] Monneveux P, Belhassen E. The diversity of drought adaptation in the wide. Plant Growth Regulation 1996; 20 85-92.

[57] Bingham IJ. Soil-root-canopy interactions. Annals of Applied Biology 2001; 138 243-251.

[58] Taylor HM, Klepper B. The role of rooting characteristics in the supply of water to plants. Advances in Agronomy 1978; 30 99-128. 
[59] Liu J, Williams J, Zehnder A, Yang H. GEPIC - modeling wheat yield and crop productivity with high resolution on a global scale. Agricultural Systems 2007; 94 478-493.

[60] Agnus JF, van Herwaarden AF. Increasing water use and water use efficiency in dryland wheat. Agronomy Journal 2001; 93 290-298.

[61] Passioura J. Increasing crop productivity when is scarce-from breeding to field management. Agricultural Water Management 2006; 80 176-196.

[62] Grzebisz W, Baer A, Barłóg P, Szczepaniak W, Potarzycki J. Effect of nitrogen and potassium fertilizing systems on maize grain yield. Fertilizers and Fertilization 2010; 40 45-56.

[63] Sheldrick WF, Syers JK, Lingard J. A conceptual model for conducting nutrient audits at national, regional and global scales, Nutrient Cycling in Agroecosystems 2002; 62 61-67.

[64] Wood S, Sebastian K, Scherr SJ. Soil resource condition. Research report: Pilot analysis of global ecosystems: Agroecosystems. Washington: World Resource Institute; 2000. p45-54.

[65] Johnston AE.3. Understanding Potassium and Its Use in Agriculture. Brussels: European Fertilizer Manufacturers Association; 2003. http://www.efma.org/ (accessed 2012-08-15).

[66] Grzebisz W. Crop plants fertilization. Part II. Fertilizers and fertilizing systems. Poznań: PWRiL, 2009, (in Polish).

[67] Sparks DL. Potassium dynamics in soils. Advances in Agronomy 1987; 6 1-63.

[68] Grzebisz W, Gawrońska-Kulesza A. Effect of crop rotation on potassium forms and their bio-availability in log-term trial on a black earth. Part I. Three-course rotation. Polish Journal of Soil Science 1995; XXVIII(2) 111-117.

[69] Benbi DK, Biswas CR. Nutrient budgeting for phosphorus and potassium in a longterm fertilizer trial. Nutrient Cycling in Agroecosystems 1999; 54 125-132.

[70] Pagel H. 1972. Vergleichende Untersuchungen über Gehalt an austauschbarem und nachlieferbaren Kalium in wichtigen Böden der ariden und humiden Tropen. Beit. Tropische und sub-tropische Landwirtschaft und Tropenveterinärmedizin, Leipzig: KMU; 1972; 10 35-51.

[71] Fotyma, M. (2007) Content of potassium in different forms in the soils of Poland. Polish Journal of Soil Science 2007; XL(1) 19-32.

[72] Manning DAC. Mineral sources of potassium for plant nutrition. A review. Agronomy for Sustainable Development 2010; 30 281-294.

[73] Robert M. 1993. K-fluxes in soils in relation to parent material and pedogenesis in tropical, temperate and arid climates. In: Potassium in Ecosystems. Proceedings of 
the $23^{\text {rd }}$ Colloquium of the International Potash Institute, 12-16 October 1992, Praha, the Czech Republic, International Potash Institute, Basel, p25-44.

[74] Jakovljević MD, Kostić NM, Antić-Mladenović SB. The availability of base elements $(\mathrm{Ca}, \mathrm{Mg}, \mathrm{Ma}, \mathrm{K})$ in some important soils types in Serbia. Proceedings for natural Sciences 2003, Matica Srpska Novi Sad; 104 11-23

[75] Sheng XF. Growth promotion and increased potassium uptake of cotton and rape by a potassium releasing strain of Bacillus edaphicus. Soil Biology and Biochemistry 2005; 37 1918-1922.

[76] Basak BB, Biswas DR. Influence of potassium solubilizing microorganism (Bacillus mucilaginosus) and waste mica on potassium uptake dynamics by sudan grass (Sorghum vulgare Pers.) grown under two alfisols. Plant Soil 2009; 317 (1/2) 235-255.

[77] Wang JG, Zhang FS, Zhang XL, Cao YP. Release of potassium from K-bearing minerals: effect of plant roots under P deficiency. Nutrient Cycling in Agroecosystems 2000; 56 45-52.

[78] Frąckowiak-Pawlak K. On bio-fertilizer effects on soil and plant properties. In: Report 2006/2007 Poznan University of Life Sciences, 2008.

[79] Bennet AJ, Bending GD, Chandler D, Hilton S, Mills P. Meeting the demand for crop production: the challenge of yield decline in crops grown in short rotations. Biological Reviews 2011. DOI: 10.1111/j.1469-185X.2011.00184.x

[80] Berzsenyi Z, Győrffy B, Lap DQ. Effect of crop rotation and fertilization on maize and wheat yields and yield stability in a long-term experiment. European Journal of Agronomy 2000; 13 225-244.

[81] Karlen DL, Varvel GE, Bullock DG, Cruse RM. Crop rotations for the $21^{\text {st }}$ century. Advances in Agronomy 1994; 53 1-45.

[82] Castellazzi MS, Wood GA, Burgess PJ, Morris J, Conrad KF, Perry JN. A systematic representation of crop rotations. Agricultural Systems 2008; 97 26-33.

[83] Struik P, Bonciarelli F. Resource use at the cropping system level. European Journal of Agronomy 1997; 7 133-143.

[84] Weaver JE. Root development of field crops. New York: McGraw-Hill BC Inc. 1926.

[85] Milford GFJ, Armstrong MJ, Jarvis PJ, Houghton BJ, Bellett-Travers DM, Jones J, Leigh RA (2000): Effect of potassium fertilizer on the yield, quality and potassium off-take of sugar beet crops grown on soil of different potassium status. The Journal Agricultural Science, Cambridge 2000; 135 1-10.

[86] Wojciechowski A, Szczepaniak W, Grzebisz W. Effect of potassium fertilization on yields and technological quality of sugar beet part I. Yields of roots and sugar. Biuletyn IHAR 2002; 222 57-64 (in Polish with English summary). 
[87] Heckman JR, Kamprath EJ. Potassium accumulation and corn yield related to potassium fertilizer rate and placement. Soil Science Society of American Journal 1992; 56 141-148.

[88] Van Noordwijk M, Brouwer G. Review of quantitative root length data in agriculture. In: McMichael BL, Persson H. (eds.) Plant roots and their environment. Amsterdam: Elsevier Science Publishers; 1991. p515-525.

[89] Van Noordwijk M, de Willigen P. Roots, plant production and nutrient use efficiency. PhD thesis. Institute of Soil Fertility, Haren (Groningen); 1987.

[90] Kerschberger M, Richter D. Neue Versorgungsstufen (VST) für den pflanzenverfügbaren K-Gehalt (DL-Methode) auf Ackerböden. Richtlinien der Düngung 1987; 11, 14-18.

[91] Janssen BH, de Willigen P. Ideal and saturated soil fertility as bench marks in nutrient management. 1. Outline of the framework. Agriculture, Ecosystems and Environment 2006; 116 132-146.

[92] Wojciechowski A, Szczepaniak W, Grzebisz W. Effect of potassium fertilization on yields and technological quality of sugar beet. Part III. Potassium uptake. Biuletyn IHAR 2002; 222 71-76. 